\title{
WORKING
}

paper

\section{Share Buybacks, Monetary Policy and the Cost of Debt}

\section{Assia Elgouacem ${ }^{1}$ and Riccardo Zago $^{2}$}

$$
\text { July 2020, WP \#773 }
$$

\begin{abstract}
Share buybacks have become common practice across U.S corporations. This paper shows that firms finance these operations mostly through newly issued corporate bonds, and that the exogenous variation in the cost of debt -due to innovations in monetary policy-is key in explaining managers' incentives to repurchase their own shares. Under our identification strategy, we find that firms are more likely to repurchase in periods of accommodative monetary policy when the yield on bond adjusts in the same direction. This behavior has macroeconomic implications as it diverts resources from investment and employment, thus reducing the transmission of accommodative monetary policy at firm-level.
\end{abstract}

Keywords: Share Buybacks, Monetary Policy, Corporate Yield, EPS Targeting.

JEL classification: E52, G11, G35, G32.

${ }^{1}$ OECD, Economics Department. assia.elgouacem@,oecd.org.

2 Directorate of microeconomic and structural analysis. riccardo.zago@banque-france.fr.

We thank Ursel Baumann, Nicola Benatti, Jess Benhabib, Barbara Biasi, Gian Luca Clementi, Nicolas Coeurdacier, Luca Dedola, Fiorella De Fiore, Stéphane Guibaud, Sergei Guriev, Laurie Hodrick, Paul Hubert, Daniel Kapp, Sydney Ludvigson, Meradj Mortezapouraghdam, Pablo Ottonello, Joanne Tan, Quentin Vandeweyer, Philip Vermeulen, Jeffrey Wurgler and participants to seminars at Sciences-Po, the OECD, Banque de France, the ECB, NYU Stern School of Business for helpful comments and suggestions. The views expressed herein are ours and should not be attributed to Banque de France or the OECD Secretariat or OECD member countries. All errors remain ours.

Working Papers reflect the opinions of the authors and do not necessarily express the views of the Banque de France. This document is available on publications.banque-france.fr/en 


\section{NON-TECHNICAL SUMMARY}

Since 1985, U.S corporations are allowed to buy back their own shares on the stock market. Very quickly buybacks have become common practice used to return cash to particular categories of investors, to send signals of confidence to markets, to concentrate firm's ownership or also to adjust stock prices. However, these operations tend to divert resources from productive investments such that many raised concerns on the legitimacy of repurchase programs, particularly on the way managers use their financial resources and on the overall impact of buybacks on the real economy. These arguments became of interest to legislators and economists in the aftermath of the Great Recession, a period in which firms -despite having at their disposal substantial internal and external liquidity- devoted massive resources to share buyback programs rather than to new investments and job openings.

In light of these facts, this paper investigates firts how firms finance share repurchases and to what extent the cost of financing affects managers' decision to buyback their own shares. We find that buyback programs are mostly financed through new corporate debt issuance and that managers are extremely sensitive to variation in the cost of debt when deciding the timing and the size of a repurchase program. This evidence allows us to relate repurchase behaviour directly to monetary policy and to study if the two interact, and whether these purely coporate-finance operations reduce the pass-through of monetary policy shocks onto real variables at firm-level. We claim that this is indeed the case. In fact, we find that buybacks are most likely and bigger in periods of accommodative monetary policy, i.e. when the cost of debt is low. In partiuclar, for an exogenous fall in the Fed fund rate, firms who benefit from a downward adjustment of their corporate yield tend to repurchase more by issuing more debt in the same quarter. Using low-cost debt to finance repurchases takes away resources from capital expenditures and new employment, thus reducing the effectiveness of accommodative monetary policy at firm-level. For example, firms befitting from a $1 \%$ fall in the corporate cost of debt -due to a accommodative monetary shock- repurchase $0.44 \%$ of their assets. However, for every million of assets, the same firms invest 11.200 dollars less and hire 0.10 workers less than those firms that do not conduct any repurchase in the same period of monetary accommodation.

Therefore, we conclude that buybacks do attenuate the transmission of expansionary monetary policy and, if the repurchase channel was muted, the transmission of a $1 \%$ accommodative shock on investments and employment would be respectively $11 \%$ and $14 \%$ stronger. 


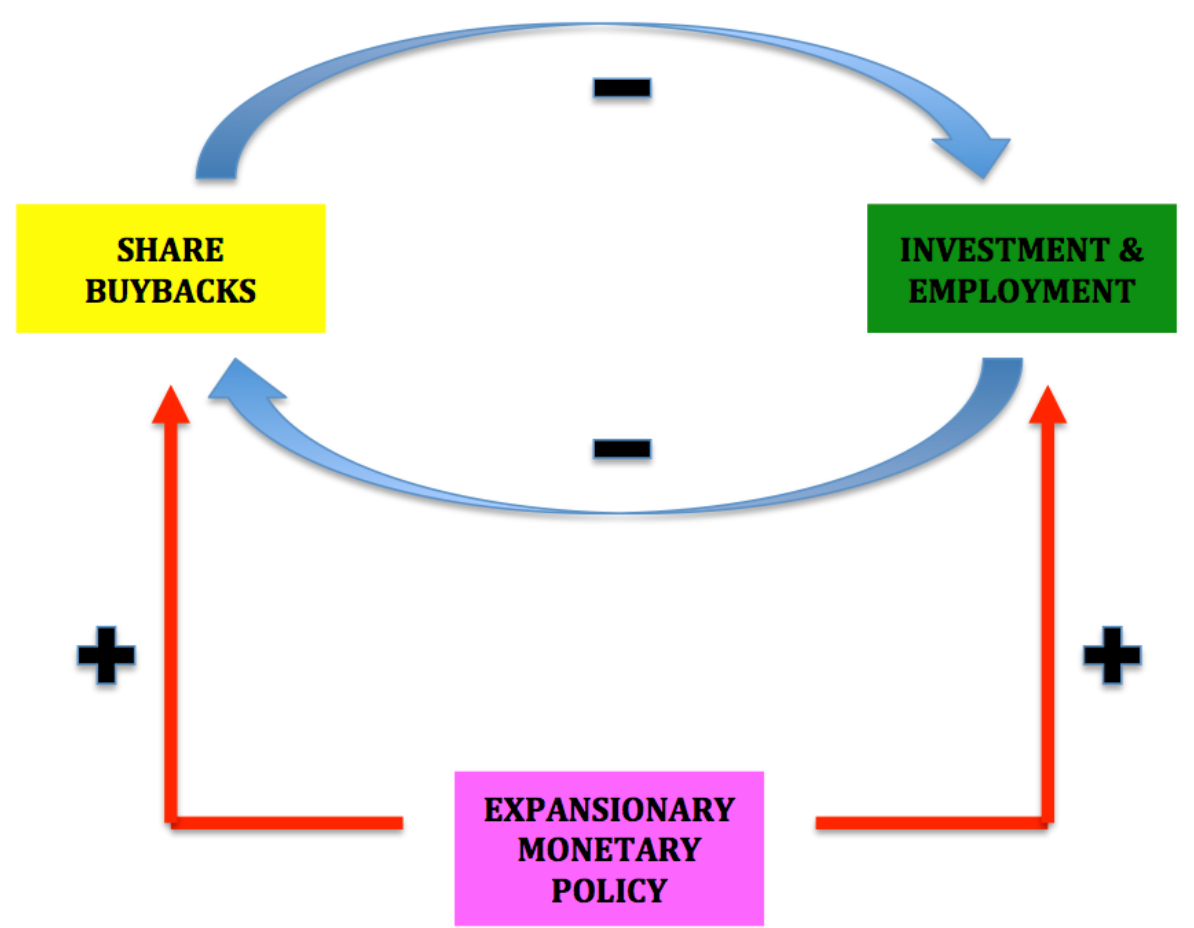

Note: this diagram shows the (endogenous) relationship between share buybacks and real variables. This paper studies how expansionary monetary policy influences both the decision to buyback and the decision to invest/ hire, and quantifies by how much share buybacks attenuate the transmission of an accommodative monetary shock on real variables at firm-level.

\section{Rachats d'actions, politique monétaire et coût de la dette}

RÉSUMÉ

Les rachats d'actions sont devenus une pratique courante des les sociétés américaines. Cet article montre que les entreprises financent ces opérations principalement par émissions de obligations et que la variation exogène du coût de la dette - due aux innovations de la politique monétaire - est essentielle pour expliquer les incitations des menagers à racheter leurs propres actions. Dans le cadre de notre stratégie d'identification, nous constatons que les entreprises sont plus susceptibles de racheter en période de politique monétaire accommodante lorsque le rendement des obligations s'ajuste dans la même direction. Ce comportement a des implications macroéconomiques car il détourne les ressources de l'investissement et de l'emploi, réduisant ainsi la transmission d'une politique monétaire accommodante au niveau de l'entreprise.

Mots-clés : rachat d'actions, politique monétaire, rendement des entreprises, ciblage du BPA.

Les Documents de travail reflètent les idées personnelles de leurs auteurs et n'expriment pas nécessairement la position de la Banque de France. Ils sont disponibles sur publications.banque-france.fr 


\section{Introduction}

Since 1985, U.S corporations are allowed to buy back their own shares on the stock market. Very quickly buybacks have become common practice used to return cash to particular categories of investors, to send signals of confidence to markets, to concentrate firm's ownership or also to adjust stock prices. However, these operations tend to divert resources from productive investments such that many raised concerns on the legitimacy of repurchase programs, particularly on the way managers use their financial resources and on the impact of buybacks on the real economy. These arguments became of interest to legislators and economists in the aftermath of the Great Recession, a period in which firms - despite having at their disposal substantial internal and external liquidity - devoted massive resources to share buyback programs rather than to new investments and job openings.

Much is already known about the negative effect of repurchases on real variables (Almeida, Fos, and Kronlund (2016)), on the market-timing of repurchases (Stein (1996), Ma (2014), Baker and Wurgler (2002)) and the reason why firms do buyback (Grullon and Michaely (2004), Hribar, Jenkins, and Johnson (2006)). Yet, little is known about how firms finance this operation and to what extent the cost of financing affects managers' decision to buyback their own shares. This paper aims to fill this gap in the literature and shows that buyback programs are mostly financed through new corporate debt issuance and they are most likely and bigger in periods of accommodative monetary policy. In fact, for an exogenous fall in the Fed fund rate, firms who benefit from a downward adjustment of their corporate yield tend to repurchase more by issuing more debt in the same quarter. Using low-cost debt to finance repurchases takes away resources from capital expenditures and new employment, thus reducing the effectiveness of accommodative monetary policy at firm-level. The contri-

bution of the paper stands on the fact that we are able to properly quantify by how much the diversion of resources to repurchase programs is due to accommodative monetary policy, and to causally assess by how much the transmission of monetary policy on real variables is attenuated by the share buyback channel.

In light of this evidence, this paper not only unveils a new fact that informs on the use of share repurchases and the allocation of firms' financial resources, but it also highlights how these corporate decisions prevent a full transmission of an expansionary monetary policy on real variables. Hence, this work is also linked to a growing literature investigating how firm-level heterogeneity influences corporate dynamics and the transmission of macroeconomic shocks to the real economy (see for example Armenter and Hnatkovska (2011), Acharya, Almeida, and Campello (2013), Bacchetta, Benhima, and Poilly (2014), Falato, Kadyrzhanova, and Sim (2013) and Bloom, Bond, and Van Reenen (2007)). 
The first part of the paper shows some basic facts that motivated our investigation and explains the main problems when measuring the effects of monetary policy on firms' repurchase decision. First, we use corporate balance-sheet data and show that, in the crosssection, firms use 75 cents of each dollar of newly issued debt to finance repurchase programs, whereas corporate cash plays a minor (if not insignificant) role. Second, we show that repurchase programs are $3 \%$ more likely and $10 \%$ larger in periods in which a $1 \%$ negative monetary policy shock realizes. However, these estimates are biased due to the fact that there are many different channels through which monetary policy can operate and influence managerial behavior.

In the second part of the paper we deal with this problem. This is not a trivial task since the relationship between buybacks, monetary policy and real variables is exposed to several sources of endogeneity: a firm can self-select into a repurchase program at any time and for reasons other than an exogenous change in the cost of debt. Similarly, there are factors monetary policy included - that can simultaneously affect employment and investment such that the decision to repurchase and the size of the buyback program might be an endogenous outcome. To solve the endogeneity issue, quantify the correct effect of monetary policy on repurchase and impute by how much the crowding-out of buybacks on real variables is due to an accommodative monetary shock, we need a rigorous identification strategy. More specifically, we need an exogenous factor, orthogonal to firm characteristics and monetary policy itself, able to explain ex-ante firms' repurchase behavior. This, in a first stage, would allow us to correctly evaluate how monetary policy influences buyback behavior by comparing the effect of monetary innovations between firms that are ex-ante supposed to repurchase and those that are not. Thereafter, in a second stage, we can use this strategy to assess the causal crowding-out effect of repurchase on real variables, by how much an accommodative monetary policy exacerbates such effect and by how much share buybacks attenuate the overall transmission of an accommodative monetary policy shock.

To do so, we exploit a discontinuity in the likelihood of repurchasing that is driven by management earnings considerations. As shown in Hribar et al. (2006), firms whose earning-per-share (EPS) ratio is below the analysts' forecast are more prone to launch an accretive buyback program in order to meet markets' expectations, build credibility and avoid markets' future punishment. ${ }^{1}$ This maneuver allows us to split the sample of firms into a "treatment" group, i.e. those who need to adjust the EPS to meet the target, and a "control" group, i.e. those who do not need to adjust the EPS to meet the target. Both

\footnotetext{
${ }^{1} \mathrm{An}$ accretive buyback program is one that raises the EPS by more than the opportunity cost of not saving resources.
} 
groups are very similar in terms of leverage, size, cost of debt, return on assets, growth opportunities and financial constraints before the EPS forecast is announced, and exhibit also similar dynamics in investments and employment. Moreover, monetary policy and the implied changes of corporate debt cost are not correlated anyhow with the EPS forecast. Hence, all the identifying assumptions for a regression discontinuity design hold and the distance from the EPS forecast is a valid predictor of repurchase behavior.

Under this strategy, first we study how an exogenous fall in the corporate cost of debt as explained by a monetary policy shock - affects both groups around the discontinuity at the moment of the EPS forecast announcement and show that it has a significant positive impact only for the "treatment" group. In other words, if a manager needs to repurchase to satisfy EPS market expectations, (s)he is more likely and capable to do so if (s)he benefits from a fall in the cost of debt at the same time, i.e. if (s)he can raise money at a low cost to finance this operation. In particular, from this analysis, we find that a $1 \%$ exogenous fall in the 10-years corporate bond yield leads to an increase of $0.44 \%$ of repurchase among firms in the "treatment" group. Thereafter, by using the distance from the EPS forecasts and monetary policy shocks as instruments, we study the causal effect of repurchases, the cost of debt and their interaction on real variables.

From this analysis, the result is that repurchases causally lead to a considerable crowdingout effect on future investments and employment and any accommodative monetary policy shock lowering the corporate cost of debt exacerbates such effect. In particular, we find that - through the repurchase channel - a $1 \%$ fall in the corporate cost of debt leads to an extra decrease of investments by 11,200 dollars and 0.10 employees for every million dollar of firm's assets. Such diversion of resources from real variables questions the effectiveness of monetary policy and its transmission at firm-level. By doing a simple back-of-the-envelope calculation, we find that indeed buybacks attenuate the transmission of expansionary monetary policy and, if the repurchase channel was muted, the transmission of a $1 \%$ accommodative shock on investments and employment would be respectively $11 \%$ and $14 \%$ stronger.

Related Literature - This paper is related to three strands of literature. The first is the vast literature on share buybacks. This tells us that repurchase are typically conducted when firms have the private information that their stock price is undervalued (Stein (1996), Ikenberry, Lakonishok, and Vermaelen (1995), Brockman and Chung (2001), Peyer and Vermaelen (2008)), when they lack future growth opportunities (Grullon and Michaely (2004)), to signal confidence to markets on strong future performance (Hribar et al. (2006), Lie (2005)), to increase employees effort (Babenko (2009)), to mitigate the dilutive effect of stock option exercises (Kahle (2002), Bens, Nagar, Skinner, and Wong (2003)), to distribute excess capital 
(Dittmar (2000)). Moreover, we know that repurchase programs follow market-timing. For example, firms repurchase when the value of equity is relatively low with respect to other sources of financing (Ma (2014), Baker and Wurgler (2002)). Finally, Almeida et al. (2016) tells us that share buybacks crowd-out future capital investment, employment and R\&D investment. Also Lazonick (2014) goes into this direction and cites repurchases as a possible explanation for why, in the post-recession era, firms have high corporate profitability but low growth in employment.

The second strand of literature this paper relates to is on earnings and EPS management. Our identification strategy is based on the fact that managers care about meeting market expectations on earnings, and it is well known that repurchases can help boost the EPS index (see among the many Graham and Harvey (2005), Skinner and Sloan (2002) and Burgstahler and Dichev (1997)).

Third, this paper relates to the growing literature studying the role of firm heterogeneity for the transmission of macroeconomic shocks and for the comprehension of macroeconomic dynamics. For example, and consistently with the results of this paper, Bacchetta et al. (2014) shows that firms exploit liquidity shocks to hoard cash for precautionary purposes at the detriment of employment. In the same vein, Armenter and Hnatkovska (2011), Falato et al. (2013), Acharya et al. (2013) and Bloom et al. (2007) show the effects of firms precautionary behavior when productivity and uncertainty shocks materialize. Others, like Melcangi (2017) and Jeenas (2018), show that demand shocks and monetary shocks heterogeneously affect firms' employment choice depending on the capital structure of the firm, the degree of financial constraint and the level of liquidity.

This paper develops as follows: Section 2 discusses EPS targeting and manipulation, and introduces a simple theoretical model showing the conditions under which a fall in the cost of debt allows for accretive repurchases; Section 3 documents the financing and the timing of repurchase programs in the data; in Section 4 we explain the identification strategy to study the causal crowding-out effect of repurchase on real variable and to impute correctly the attenuation of accommodative monetary policy due to buybacks; in Section 5 we do robustness checks. Section 6 concludes.

\section{EPS Manipulation and the Cost of Money}

The EPS ratio can be manipulated by corporate managers through several channels. In order to understand each of them, consider the following definition for the earning-per-share ratio:

$$
E P S=\frac{(1-\tau)\left[y-r^{s} n P\right]}{N-n}
$$


where $y$ is firm's profit at the net of production and financial costs, $\tau$ is the firm specific taxation rate, $P$ is the current stock price, $n$ is the number of own shares repurchased, $r^{s}$ is the return on a 3-months government bond and $N$ is the number of outstanding shares.

Manipulation of the EPS can occur through two channels that both have the common goal of meeting or superseding analysts' forecast. The first channel is through profit management (y). As shown in Burgstahler and Dichev (1997), it is very unlikely for listed firms to report losses. In fact, they would rather manipulate their cash flow or reduce operating costs and working capital than report earnings below market expectations. Degeorge, Patel, and Zeckhauser (1999) and Burgstahler and Eames (2006) demonstrate that distance from the analysts' EPS or sales forecast triggers managerial strategic behavior on profits in order to immediately please shareholders, even though this strategy often comes at the cost of worse performance in the near future. The second channel through which firms can manipulate their EPS is share buybacks $(n)$ (see Bens et al. (2003)), which is not uniquely used to tilt the EPS to market expectations. In fact, as in a signaling game, managers tend to repurchase their own shares also because it is an effective tool to build credibility and preserve their reputation on capital markets, to increase stock prices and avoid uncertainty and further speculation (see Vermaelen (1981) and Grullon and Ikenberry (2000)).

Either through profit management $(y)$ or buybacks $(n)$, managers care about meeting or beating the analysts' EPS forecast because it leads to a valuation premium. As Bartov, Givoly, and Hayn (2002), DeFond and Park (2000) and Kasznik and McNichols (2002) document, firms that are able to meet the forecast enjoy (cumulative) abnormal returns in the next quarters. Moreover, if firms' strategic behavior is consistent over time, capital markets tend to give greater valuation on their fundamentals because the capability to meet the target throughout time is a good and reliable indicator for future performance. On the other hand, there is evidence that managers are punished when failing to meet the target. As in Skinner and Sloan (2002) and Kinney, Burgstahler, and Martin (2002), missing the target by one cent causes a significant decline in stock prices and the value of the firm.

Yet, share repurchases are not always effective in increasing the EPS ratio, i.e. they are not always accretive. In fact, since $n$ appears in both the numerator and denominator, a repurchase program is effective in increasing the EPS only if the change in the denominator dominates the change in the numerator. Hribar et al. (2006) states that a repurchase program is accretive, i.e. $\partial E P S / \partial n>0$, if the following condition holds:

$$
P<\frac{E P S}{r^{s}(1-\tau)} .
$$


We start from this condition to think about how the cost of money matters for managers when conducting an accretive repurchase. As from the derivation above, for a given $E P S$, $P$ and $\tau$, the higher $r^{s}$ the more difficult it is for a firm to launch an accretive repurchase. However, this intuition is not necessarily true, since an exogenous change in the value of money changes managers' incentive to issue new debt, to buy new capital and to change their leverage position. This endogenous adjustment in the capital structure will ultimately affect production and profits. These are key variables that must be taken into account when considering launching an accretive repurchase program.

For these reasons, we introduce a simple - but more general - static model to show how negative changes in the cost of debt trigger new debt issuance and allow for accretive repurchases, regardless of the endogenous adjustments of capital and its effect on production. Following the work of Stein (1996), we imagine a firm characterized by a leverage ratio $d$, choosing today the level of capital $K$, debt $B$ and the quantity $n$ of shares to be repurchased. ${ }^{2}$ The firm is a price taker on the equity, bond and capital markets such that the stock price $P$, the cost on newly issued debt $r^{B}$ and the unitary cost of capital are all observed at the beginning of the period and taken as given. Also, we assume that the firm-specific cost of debt is proportional to the minimum return $r^{s}$ on a saving account in a linear fashion, i.e. $r^{B}=\kappa r^{s}$, with $\kappa>1$. Once the factors of production and the capital structure are chosen, the firm starts production with a final output (sales) equal to $f(K)=z K^{\alpha}$, with $\alpha \in(0,1)$ and $z$ being the productivity of the firm.

Given this setup, managers who are willing to launch an accretive repurchase face the following problem:

$$
\max _{K, B, n} \Omega=\frac{(1-\tau)\left[f(K)-r^{B} B-r^{s} n P\right]}{N-n}-\frac{\theta}{2}[B-d K]^{2}
$$

In words, they maximize the EPS of the firm (the first element of the objective function $\Omega$ ), taking into account the quadratic cost that arises due to deviations from the original leverage ratio $d$ (the second element of the objective function $\Omega$ ). ${ }^{3}$ Under this formulation, earnings are defined as the after-tax income generated from production once the firm pays the interests on debt and report the forgone earnings if the amount of money spent in the repurchase was instead kept on a saving account. The maximization problem is subject to the firm's budget constraint $K=B-n P$, such that capital is financed through debt at the net of the amount of money allocated to repurchases. Substituting the budget constraint

\footnotetext{
${ }^{2}$ If $n<0$, then the firm is a net equity issuer.

${ }^{3}$ Note that, under this formulation, $d$ is the targeted leverage of the firm. Hence, for a level of capital $K$, the debt issued $B$ should be equal to $d k$. Deviation from the targeted leverage leads to a quadratic cost with weight $\theta$, a proxy for capital structure flexibility.
} 
into the objective function reduces the problem by one dimension and gives us the following first order conditions.

Lemma 1. Managers maximize the EPS under quadratic capital adjustment costs if

i) $\frac{\partial \Omega}{\partial B}=0$, i.e. $(1-\tau)\left[f^{\prime}-r^{B}\right]=\theta(1-d)[B(1-d)+d n P](N-n)$

ii) $\frac{\partial \Omega}{\partial n}=0$, i.e. $E P S=(1-\tau) P\left[f^{\prime}+r^{s}\right]+\theta d[(1-d) B+d n P] P(N-n)$

where condition (i) states that the net marginal income from an extra unit of debt must be equal to the marginal cost of changing the capital structure through higher bond issuance, while condition (ii) states that the level of repurchase is optimal if the manipulated EPS is equal to the sum of the marginal loss in net income from diversion of resources from production and savings on a safe asset, and the marginal cost of changing the capital structure due to higher buybacks. The solution of the system of equations (i) and (ii) leads to the equilibrium $B^{*}, n^{*}$ and therefore $K^{*}=B^{*}-n^{*} P$.

In order to understand how changes in the cost of money affect the equilibrium, we perturbate the equilibrium conditions by a marginal change in the interest rate $r^{s}$. This leads to the following.

Proposition 1. For $\theta$ small, a marginal decrease in the interest rate leads to higher debt issuance $\left(\partial B^{*} / \partial r^{s}<0\right)$, higher repurchase $\left(\partial n^{*} / \partial r^{s}<0\right)$ and higher EPS $\left(\partial E P S^{*} / \partial r^{s}<\right.$ $0)$. In other words, debt issuance, share buybacks and EPS are correlated with changes in the cost of money.

Proof. See Appendix B

Under Proposition 1, we gain two insights. First, launching a repurchase program affects mechanically more the denominator than the numerator of the EPS ratio: for an extra share repurchased, the fall in net income is smaller than the fall in the number of outstanding shares. Second, for a marginal fall in the interest rate, the capital structure of the firm changes in favor of debt despite the quadratic cost of over-leveraging, and managers buyback more. Figure 1 plots the change in the optimal level of the endogenous variables $\left(E P S^{*}\right.$, $\left.B^{*}, n^{*}\right)$ on the (negative) change of the interest rate $r^{s}$. Again, a decrease in $r^{s}$ leads to an increase in $E P S^{*}, B^{*}, n^{*}$. This is because a lower cost of money allows the firm to increase its leverage and use debt to buyback its shares in order to increase the EPS ratio. Yet, we still do not know whether this necessarily leads to a fall or increase in investments. In fact, the crowding-out effect on capital investments $\left(\partial K^{*} / \partial n^{*}<0 ; \partial K^{*} / \partial r^{s}>0\right)$ depends 
Fig. 1. Comparative Statics
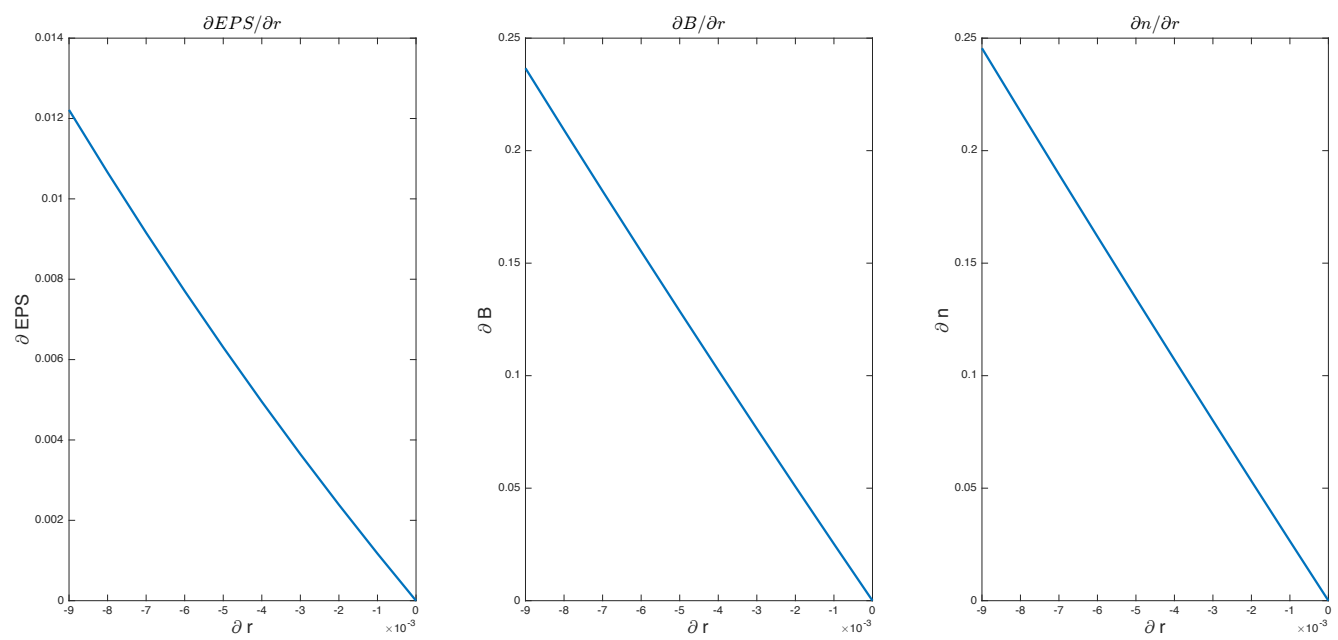

Notes: The picture plots marginal changes in the model endogenous variables $B^{*}, n^{*}$ and implied $E P S^{*}$ for negative marginal changes in the interest rate $r^{s}$.

heavily on model parametrization, in particular on the return to scale parameter $\alpha$, the firm productivity level $z$, and the flexibility of the capital structure $\theta$.

In light of this simple model, in the next sections we empirically show (i) how firms finance repurchases and when; (ii) how the change in the cost of debt helps firms launch accretive repurchases; (iii) if the crowding-out effect of share repurchases on investment and employment is affected by changes in the cost of debt.

\section{Repurchases, Debt and Monetary Policy}

In this section, we describe the data and provide some basic evidence on how share buybacks, debt issuance and monetary policy are all related. In particular, we show three facts. First, firms finance repurchase programs by issuing new debt and cutting their capital expenditures. Second, the timing and magnitude of buybacks programs are correlated with unanticipated changes in monetary policy: they are more probable and larger in periods of accommodative monetary policy, i.e. when the cost of money is lower. Third, monetary shocks have a firm-specific effect on debt issuance through changes in the yield on corporate bonds that would influence the size of repurchase programs. 
Table 1: Descriptive Statistics

\begin{tabular}{|c|c|c|c|c|c|c|c|c|c|c|}
\hline Repurchase Statistics & Mean & 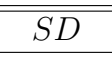 & $\overline{p p 1}$ & $\overline{p 5}$ & $p 25$ & p550 & $\overline{p p 75}$ & $\overline{p p 95}$ & $\overline{p p 99}$ & $\bar{N}$ \\
\hline $\mathbb{I}($ Repurchases $>0)$ & .24 & .43 & 0 & 0 & 0 & 0 & 0 & 1 & 1 & 831,649 \\
\hline \multicolumn{11}{|l|}{ For $\mathbb{I}($ Repurchases $>0)=1$} \\
\hline Repurchases/Assets & .03 & .06 & .00 & .00 & .00 & .01 & .03 & .12 & .30 & 204,794 \\
\hline Repurchases $(\$ M)$ & 38.27 & 88.90 & .00 & .02 & .36 & 3.141 & 25.56 & 229.51 & 474.184 & 204,794 \\
\hline EPS Distance Statistics & Mean & 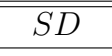 & $p 1$ & $p 5$ & $p 25$ & $p 50$ & $p 75$ & $p 95$ & $p 99$ & 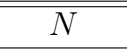 \\
\hline Distance (\%) & -.07 & 1.91 & -7.33 & -3.34 & -.48 & .04 & .61 & 2.30 & 5.91 & 196,378 \\
\hline $\mathbb{I}($ Distance $\geq 0)$ & .54 & .49 & 0 & 0 & 0 & 1 & 1 & 1 & 1 & 196,378 \\
\hline $\mathbb{I}($ Distance $<0)$ & .46 & .49 & 0 & 0 & 0 & 0 & 1 & 1 & 1 & 196,378 \\
\hline Firm Characteristics & Mean & 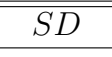 & $\overline{p p 1}$ & $p 5$ & $p 25$ & $p 50$ & $p 75$ & $p 95$ & $p 99$ & $\overline{N N}$ \\
\hline Market Cap. $(\$ M)$ & 2,630 & 14,901 & .33 & 2.02 & 22.70 & 141.86 & 876.99 & 9,428 & 46,011 & 248,137 \\
\hline Market-to-Book & 3.46 & 4.98 & .15 & .41 & 1.11 & 1.98 & 3.65 & 11.46 & 28.16 & 211,214 \\
\hline Assets $(\$ M)$ & 1,946 & 13,13 & .02 & .91 & 14.43 & 84.68 & 507.06 & 6,533 & 34,235 & 831,649 \\
\hline Money/Assets & .17 & .19 & .00 & .00 & .03 & .09 & .23 & .63 & .88 & 223,742 \\
\hline Profits/Assets & -.01 & .19 & -.79 & -.42 & -.03 & .02 & .06 & .17 & .33 & 586,650 \\
\hline Debt/Assets & .23 & .20 & .00 & .00 & .05 & .18 & .34 & .65 & .87 & 562,305 \\
\hline Investments/Assets & .04 & .07 & .00 & .00 & .00 & .02 & .05 & .17 & .40 & 723,171 \\
\hline Employment/Assets & 16.98 & 22.01 & .08 & .41 & 2.44 & 5.72 & 12.12 & 36.44 & 110.49 & 653,749 \\
\hline $10-Y$ ears Yield $(\%)$ & 5.20 & 2.52 & 1.38 & 2.07 & 3.41 & 4.88 & 6.34 & 9.59 & 14.67 & 48,560 \\
\hline$Q$ & 2.43 & 2.61 & .35 & .65 & 1.09 & 1.55 & 2.58 & 7.51 & 14.97 & 234,911 \\
\hline$R O A$ & -.04 & .18 & -.93 & -.29 & -.03 & .00 & .01 & .05 & .16 & 790,956 \\
\hline$P E 10$ & 21.74 & 352.78 & .03 & .15 & 1.10 & 3.50 & 10.65 & 52.94 & 212.20 & 95,314 \\
\hline $\mathbb{I}($ Dividend $>0)$ & .16 & .37 & 0 & 0 & 0 & 0 & 0 & 1 & 1 & 831,649 \\
\hline Fin. Constraint & -2.58 & 0.72 & -3.27 & -3.25 & -3.11 & -2.79 & -2.28 & -1.27 & -.15 & 351,375 \\
\hline Monetary Innovations & Mean & $\overline{S S D}$ & $p 1$ & $p 5$ & $p 25$ & $\overline{p 550}$ & $p 75$ & $\overline{p 95}$ & $\overline{p 999}$ & 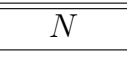 \\
\hline Shock (\%) & 0.00 & 0.11 & & & & & & & & 128 \\
\hline
\end{tabular}

Notes: All the variables are build on quarterly data. Repurchases is the difference between stock purchases and stock issuances (in $\$ M$ ). Distance is the difference between the reported EPS and the median EPS forecast at the end of the quarter, normalized by the end-of-quarter stock price. Market-to-Book is the market value of common equity divided by the book value of common equity. Money is the total value of cash holdings (in $\$ M$ ). Profits is defined as net income plus depreciation (in $\$ M$ ). Debt is the value of total debt (in $\$ M$ ). Investments equates capital expenditure (in $\$ M$ ). Employment is the stock of employees (in $K \mathrm{~s})$. Yield is the firm's yield on a 10-years-maturity corporate bond. $Q$ is the book value of liabilities plus the market value of common equity divided by the book value of assets. $R O A$ is net income (in $\$ M$ ) divided by lagged assets (in $\$ M$ ). The measure of Fin. Constraint follows Hadlock and Pierce (2010). PE10 is the 10-quarter-moving-average of the price-earning ratio. Shock is the monetary shock obtained from a SVAR (see Appendix A). 


\subsection{Data and sample selection}

In order to study the impact of an exogenous change in the cost of debt on repurchases and the consequent crowding-out effect on real variables (capital investment and employment), we use two types of data: firm-level data and macroeconomic data on monetary policy shocks. Firm micro-data comes from different sources. We use Standard and Poor's Compustat to extract firms' fundamentals data at quarterly frequency between 1985 and 2016. Following Almeida et al. (2016), we exclude regulated utility firms (standard Industrial Classification (SIC) codes 4800-4829 and 4910-4949) and financial firms (SIC 6000-6999) as well as firms with missing or negative assets. Thereafter, we merge the Compustat sample with analysts' forecast data from Institutional Brokers' Estimate System (IBES). Finally, we use data from Trade Reporting and Compliance Engine (TRACE) to extract firm-level yields on newly and previously issued corporate bonds. ${ }^{4}$ Regarding monetary policy shocks, we follow the literature on structural VAR and recent developments as in Ramey (2016) and Rossi and Zubairy (2011) to extract innovations on the fund rate. ${ }^{5}$ Table 1 shows summary statistics of the variables we use and it describes their construction. In particular, as in Ma (2014), we define repurchase as the firm's net position on the equity market, i.e. difference of the value of the shares repurchased and the value of the newly issued shares normalized by total assets in the previous period. In this way, a negative value would stand for a net equity issuance while a positive value for a net equity repurchase. As the first panel of Table 1 reports, $24 \%$ of firms are net repurchasers across quarters. Among them, on average 3.1\% of assets are repurchased every period with an average cash flow of 38 million dollars. The second panel reports statistics on firm's ex-post EPS distance from the analysts' target and frequency for a (weakly) positive and negative distance from the target. Such distance is measured as the difference between the EPS forecast and the end-of-the-quarter EPS as reported by the firm. The (price-normalized) average distance is negative and $0.07 \%$ off the median analysts' consensus. Across quarters, $54 \%$ of the time firms are on target or above (i.e. they are reporting an end-of-the-quarter EPS at least as big as the forecast) while $46 \%$ of the time they are below the target (i.e. they are reporting an end-of-the-quarter EPS below the forecast). The third panel reports on other firm characteristics like market capitalization, the market-to-book value of the firm, assets, internal and external financial resource (cash holdings, profits, debt issuance), investments, employment, the cost of debt (measured as the yield on a 10-years corporate bond), the Q-value, return on assets (ROA), the 10-quarters-

\footnotetext{
${ }^{4}$ Firm level yields are calculated using equal weighted average on the different bonds issues of the same maturity.

${ }^{5}$ See Appendix A for details on the SVAR model we use to extract monetary policy shocks and its identifying assumptions.
} 
moving average of the price-earning ratio (PE10), an indicator on whether the firm has payed dividends in the previous four quarters, and a measure for financial constraint (build after Hadlock and Pierce (2010)). The fourth panel reports the mean and standard deviation of monetary policy innovations as extracted from the SVAR. These shocks have mean zero and standard deviation equal to 11 base points, very similarly to monetary shocks identified in Gertler and Karadi (2015) and Ottonello and Winberry (2018).

\subsection{The financing of share buybacks}

How are share buybacks financed? In the spirit of the our model in Section 2, we answer this question by considering the following "accounting equation" for firms conducting a (positive net) share repurchase: ${ }^{6}$

Repurchases $_{i, t}=\beta_{1} \Delta$ Debt $_{i,(t, t-1)}+\beta_{2} \Delta$ Cash $_{i,(t, t-1)}+\beta_{3}$ Investment $_{i, t}+\beta_{4}$ Dividends $_{i, t}+\epsilon_{i, t}$.

Under this specification, we want to understand how much of each dollar that the firm spends on repurchases is financed through the change in debt $\left(\beta_{1}\right)$, the change in cash holdings including net profits from the current quarter $\left(\beta_{2}\right)$, a reduction in capital expenditure $\left(\beta_{3}\right)$ or in dividend distribution $\left(\beta_{4}\right)$. All variables are normalized by the level of assets in $t-4$. As reported in the first column of Table 2, unconditionally on other sources of financing, a $1 \$$ repurchase is explained by $0.75 \$$ of new debt issuance. Controlling for the change in cash holding and quarterly profits (column 2) does not affect the role of debt by much. Moreover, the estimate for $\Delta$ Cash is insignificant, suggesting that firms do not use their liquidity from cash-holdings or newly generated net profits to finance this operations. This is consistent with the trend across U.S. corporations of hoarding cash for precautionary savings (see Falato et al. (2013) and Acharya et al. (2013)). When controlling for all other variables in the accounting equation, as well as time and industry fixed effects - as in column (3) to (5) - the contribution of debt drops to around 40 cents whereas now the increase in repurchases is mostly explained by a reduction in capital expenditure (around 62 cents). To sum up, debt plays a crucial role in the financing of repurchase whereas other financial resources, as cash holdings and current profit, do not. Also dividend distribution does not affect share buybacks. On the other hand, it seems that repurchases are mainly financed through a reduction in capital investments. ${ }^{7}$

\footnotetext{
${ }^{6}$ We consider only firms for which the difference of the value of the shares repurchased and the value of the newly issued shares is positive.

${ }^{7}$ See other specifications in Appendix C.
} 
Table 2: Financing Buybacks

\begin{tabular}{|c|c|c|c|c|c|}
\hline & $\begin{array}{c}(1) \\
\text { Repurchases }\end{array}$ & $\begin{array}{c}(2) \\
\text { Repurchases }\end{array}$ & $\begin{array}{c}(3) \\
\text { Repurchases }\end{array}$ & $\begin{array}{c}(4) \\
\text { Repurchases }\end{array}$ & $\begin{array}{c}(5) \\
\text { Repurchases }\end{array}$ \\
\hline$\Delta D e b t$ & $\begin{array}{c}0.75^{* * *} \\
(0.11)\end{array}$ & $\begin{array}{c}0.79^{* * *} \\
(0.07)\end{array}$ & $\begin{array}{c}0.40^{* * *} \\
(0.05)\end{array}$ & $\begin{array}{c}0.40^{* * *} \\
(0.05)\end{array}$ & $\begin{array}{c}0.40^{* * *} \\
(0.05)\end{array}$ \\
\hline$\Delta$ Cash & & $\begin{array}{l}-0.23 \\
(0.31)\end{array}$ & $\begin{array}{l}-0.00 \\
(0.03)\end{array}$ & $\begin{array}{l}-0.00 \\
(0.03)\end{array}$ & $\begin{array}{l}-0.00 \\
(0.03)\end{array}$ \\
\hline Investments & & & $\begin{array}{c}-0.62^{* * *} \\
(0.04)\end{array}$ & $\begin{array}{c}-0.62^{* * *} \\
(0.04)\end{array}$ & $\begin{array}{c}-0.62^{* * *} \\
(0.04)\end{array}$ \\
\hline Dividends & & & & $\begin{array}{c}0.06 \\
(0.05)\end{array}$ & $\begin{array}{c}0.06 \\
(0.05)\end{array}$ \\
\hline Observations & 180,436 & 163,278 & 144,858 & 144,858 & 144,858 \\
\hline Time FE & No & No & No & No & Yes \\
\hline Industry FE & No & No & No & No & Yes \\
\hline Controls & No & No & No & No & No \\
\hline
\end{tabular}

Notes: Standard errors in parentheses, clustered at firm level. The unit of observation Repurchases is the difference between the value of stock purchases and stock issuances from the statement of cash flows, and we consider only firms for which such difference is strictly positive. $\Delta$ Debt is the change in the value of current total debt of the firm. $\Delta$ Cash is the change in firm money holding plus current net profit. Investments is equal to capital expenditure. Dividends is equal to the value of the dividends payed. All variables are normalized by the value of total assets in $t-4 .{ }^{*}, * *, * * *$ indicate significance at $1 \%, 5 \%$ and $10 \%$ level.

\subsection{Share buybacks and monetary policy}

The fact that debt is a main source to finance buybacks suggests that these corporate operations might be sensitive to changes in the cost of money, i.e. changes in monetary policy. Yet, to measure the exact impact of monetary policy on repurchase is subject to many sources of bias since any exogenous change in the cost of money might influence other firms' decisions, for instance investment and employment, such that repurchase is an endogenous outcome. To comprehend better this fact and show what is the main problem when assessing the impact of monetary policy on the repurchase, consider the following regressions:

$$
\begin{gathered}
\mathbb{I}\left(\text { Repurchases }_{i, t+1}>0\right)=\alpha+\beta \text { Shock }_{t}+X_{i, t}^{\prime} \gamma+Z_{i, t}^{\prime} \mu+\theta_{t}+\epsilon_{i, t} \\
\text { Repurchases }_{i, t+1}=\alpha+\beta \text { Shock }_{t}+X_{i, t}^{\prime} \gamma+Z_{i, t}^{\prime} \mu+\theta_{t}+\epsilon_{i, t}
\end{gathered}
$$

where $\mathbb{I}\left(\right.$ Repurchasse $\left._{i, t+1}>0\right)$ takes value one when the firm is a gross repurchaser in quarter $t+1$, Shock $k_{t}$ is the exogenous innovation on the fund rate as predicted by our SVAR, $X$ controls for firm-level characteristics such as net income, Q-value of investment, a dummy 
indicating whether the firm has redistributed dividends in the first previous four quarters, a dummy indicating the quintile of asset the firms belong to,${ }^{8} Z$ controls for capital investment and employment, $\theta$ is a year-quarter fixed effect. ${ }^{9}$

Table 3: Net Repurchases and Monetary Policy Shocks

\begin{tabular}{lcccc}
\hline \hline & $(1)$ & $(2)$ & $(3)$ & $(4)$ \\
& $\mathbb{I}($ Repurchases $>0)$ & $\mathbb{I}($ Repurchases $>0)$ & Repurchases & Repurchases \\
\hline \multirow{3}{*}{ Shock } & $-0.03^{* * *}$ & $-0.03^{* * *}$ & $-0.16^{* *}$ & $-0.10^{*}$ \\
& $(0.00)$ & $(0.00)$ & $(0.07)$ & $(0.05)$ \\
& & & & \\
\hline Observations & 213,761 & 171,144 & 213,761 & 171,144 \\
Time FE & Yes & Yes & Yes & Yes \\
Industry FE & Yes & Yes & Yes & Yes \\
Controls $(X)$ & Yes & Yes & Yes & Yes \\
Controls $(Z)$ & No & Yes & No & Yes \\
\hline \hline
\end{tabular}

Notes: Standard errors in parentheses, clustered at firm level. In model (1) and (2), the unit of observation is $\mathbb{I}($ Repurchases $>$ $0)$, an indicator variable taking value one if the firm is a gross repurchaser, i.e. the difference between equity repurchased and new equity issuance is positive. In model (3) and (4), the unit of observation Repurchases is the difference between the value of stock purchases and stock issuances from the statement of cash flows, normalized by total asset in $t-4$. Shock is an exogenous monetary innovation as from a SVAR (see Appendix A for details). The set of controls $X$ includes net income, normalized by total asset in $t-4, \mathrm{Q}$-value of investment, a dummy indicating whether the firm has redistributed dividends in the first previous four quarters, a dummy indicating the quintile of asset the firms belong to. $Z$ controls for the level of capital expenditure and the stock of employment, both normalized by total asset in $t-4 . *, * *, * *$ indicate significance at $1 \%, 5 \%$ and $10 \%$ level.

The first two columns of Table 3 report results for model (1) under different set of controls. As from column (1), where we control for $X$ only, we find that a $1 \%$ exogenous fall of the Fed fund rate leads to an increase in the probability of repurchase by $3 \%$. As mentioned above, to interpret the $\beta$ coefficient in a causal sense and be sure that it is not biased, we need to control also for $Z$, i.e. that the relationship between the monetary policy shock and investment and employment decision has no feedback on the probability of launching a repurchase program. As from column (2), the effect of the monetary policy shock does not change, and the $\beta$ coefficient is not biased by the relationship between the shock and real variables. Therefore, we can conclude that monetary policy causally affects firms in their propensity to buyback its shares. The last two columns of Table 3 report results for model (2). As from column (3), where we control for only $X$, we find that a $1 \%$ exogenous fall in the Fed fund rate leads to a $16 \%$ increase in the level of repurchase. However, when we control also for real variables in column (3), we see that the effect falls to $10 \%$ and it is significant at the $10 \%$ level only. In other words, in column (4) we were overestimating the impact of monetary policy on the level of repurchase. This happens since the monetary

\footnotetext{
${ }^{8}$ The set of control variables $X$ will remain the same throughout the paper, if not else specified.

${ }^{9}$ The year-quarter fixed effect implies controlling for a year dummy and a quarter dummy separately.
} 
policy shock also influences real variables such that repurchasing might be a consequential (endogenous) outcome of investment and employment decisions. Therefore, the presence of the bias does not allow for a precise measure of the effect of monetary policy on the level of share repurchase.

\subsection{Corporate yield and monetary policy}

Repurchase programs are more likely and larger in periods of (exogenous) accommodative monetary policy. However, it is not plausible to assume that common monetary shocks affect all firms in the same way. In fact, monetary shocks affect firms' capital structure and decision on new debt issuance depending on the responsiveness of the firm's bond yield to the shock. The following regressions investigate the effect of the unanticipated monetary shock on firmlevel bond yields and debt issuance:

$$
\begin{gathered}
\Delta \text { Yield }_{i,(t+1, t)}=\alpha_{1}+\beta_{1} \text { Shock }_{t}+X_{i, t}^{\prime} \gamma_{1}+Z_{i, t}^{\prime} \mu_{1}+\theta_{t}+\epsilon_{i, t} \\
\Delta \text { Debt }_{i,(t+1, t)}=\alpha_{2}+\beta_{2} \Delta \text { Yield }_{i,(t+1, t)}+X_{i, t}^{\prime} \gamma_{2}+Z_{i, t}^{\prime} \mu_{2}+\theta_{t}+\nu_{i, t}
\end{gathered}
$$

where the variable $Y$ ield $d_{i}$ is firm $i$ 's yield on a 10-years-maturity corporate bond. The first two columns of Table 4 show results for regression (3). In column (1), where we control for $X$ only, we find that an exogenous innovation of $10 \mathrm{bps}$ over the fund rate leads to an increase by $6.1 \mathrm{bps}$ of the 10 -years yield. This result is robust when controlling for real variables, as shown in column (2). The results of regression (4) are reported in column (3) and (4) of Table 4. As from column (3), where we control for $X$ only, we find that a $1 \%$ fall in the yield is associated with an increase of debt issuance by $0.1 \%$. This result is significant at $10 \%$ level only. Adding controls for real variables $(Z)$ does not change the magnitude of the

coefficient of interest, but affects its significance now increased to $95 \%$ (column (4)). Since the relationship between debt issuance and changes in the yield is endogenous, we instrument $\Delta Y$ ield of equation (4) with the exogenous monetary innovations, i.e. we use equation (3) as 1 st stage to predict the exogenous change in the yield $\Delta \widehat{\text { Yield }}$. Then we use the latter to explain the causal effect of an exogenous change of the yield on debt issuance. As reported in column (5), the (2SLS) estimator is 4 times larger: if the yield exogenously falls by $1 \%$, the firm will issue $0.4 \%$ more debt. 
Table 4: Corporate Bond Yield, Debt Issuance and Monetary Shocks

\begin{tabular}{lccccc}
\hline \hline & $(1)$ & $(2)$ & $(3)$ & $(4)$ & $(5)$ \\
& $\Delta$ Yield & $\Delta$ Yield & $\Delta$ Debt & $\Delta$ Debt & $\Delta$ Debt \\
\hline \multirow{5}{*}{ Shock } & $0.61^{* * *}$ & $0.62^{* * *}$ & & & \\
& $(0.11)$ & $(0.11)$ & & & \\
& & & & & \\
$\Delta$ Yield & & & $-0.001^{*}$ & $-0.001^{* *}$ & \\
& & & $(0.00)$ & $(0.00)$ & \\
$\Delta \widehat{Y i e l d}$ & & & & $-0.004^{* * *}$ \\
& & & & & $(0.01)$ \\
& & & & & \\
\hline Observations & 41,624 & 40,458 & 41,624 & 40,458 & 40,458 \\
Time FE & Yes & Yes & Yes & Yes & Yes \\
Industry FE & Yes & Yes & Yes & Yes & Yes \\
Controls $(X)$ & Yes & Yes & Yes & Yes & Yes \\
Controls $(Z)$ & No & Yes & No & Yes & Yes \\
Estimator & Ols & Ols & Ols & Ols & 2 sls \\
\hline \hline
\end{tabular}

Notes: Standard errors in parentheses, clustered at firm level. In model (1) and (2) the unit of observation $\Delta Y$ ield is the change in the firm's yield on a 10-years-maturity corporate bond. In model (3) and (4), the unit of observation $\Delta D e b t$ is the change in the value of current total debt of the firm, normalized by total asset in $t-4$. Shock is an exogenous monetary innovation as from a SVAR (see Appendix A for details). $\Delta \widehat{\text { Yield }}$ is the exogenous change in the 10-years corporate yield as predicted by monetary policy shocks, i.e. when Shock is used as instrument for the change in the cost of debt. Column 5 reports 2SLS estimates for equation (4). Control $X$ includes net income normalized by total asset in $t-4$, Q-value of investment, a dummy indicating whether the firm has redistributed dividends in the first previous four quarters, a dummy indicating the quintile of asset the firms belong to. Control $Z$ includes the level of capital expenditure and the stock of employment, both normalized by total asset in $t-4 . * * *, * * *$ indicate significance at $1 \%, 5 \%$ and $10 \%$ level.

\section{Identifying the Effect of Monetary Policy on Real Variables through the Repurchase Channel}

In the previous section, we showed that the timing and size of buyback programs comove with monetary policy shocks. We established also that, when measuring the effect of monetary policy on the level of repurchase, our estimates are biased since monetary policy interacts with many other firm's characteristics and time-varying variables (in particular real variables) that might influence indirectly the size of the buyback program at the same time.

In fact, the option of buying back shares is always at managers' disposal and buybacks can happen for a long list of (endogenous) factors - such like poor growth prospects, lack of investments opportunities, or a need to adjust the balance-sheet structure - that might correlate with monetary policy as well. Moreover, monetary policy might directly influ- 
ence managers' choices over investment and employment such that repurchases might be a subsequent endogenous result. In other words, our identification is exposed to endogeneity problems mainly due to endogenous self-selection into a buyback program and reversed causality between repurchases and real variables (investment and employment). Therefore, monetary policy cannot explain alone repurchase behavior. In order to assess how much monetary policy encourages buybacks, first we must solve this issue. In particular, we need an exogenous factor, orthogonal to firm-level characteristics and monetary policy, capable to predict ex-ante the repurchase behavior of the firm and to split the sample in two groups: repurchasers and non-repurchasers. This allows us to break the loop between monetary policy, repurchases and real variables, and - more importantly - to assess correctly how exogenous changes in monetary policy affect both groups in their capability to repurchase. Finally, this strategy allows us to study the causal crowding-out effect of repurchase on real variables and evaluate by how much of such crowding-out is causally explained by accommodative monetary policy. By doing so, we will be able to quantify the extent to which an accommodative monetary policy shock transmits on real variables and by how much share buybacks reduce such transmission.

\subsection{Identification strategy}

In order to overcome the endogeneity problem, we exploit a discontinuity in the level and probability of conducting an accretive repurchase. This discontinuity, first introduced by Hribar et al. (2006) and recently used in Almeida et al. (2016), exploits the misalignment between the firm EPS and the analysts forecast. At the beginning of each quarter, analysts release their forecast for what the EPS of the firm will be at the end of that same quarter. Once the forecast is observed, managers decide whether to launch or not a buyback program to align their EPS at least with the level predicted by analysts. At the end of the quarter, firms announce their (manipulated) EPS along with information on the quantity and buying price of the repurchased shares. Hence, it is possible to reconstruct what the EPS would have been without repurchasing, i.e. the non-manipulated EPS (or the counterfactual) that would have prevailed without repurchase. This information allows us to understand which firms were able to run an accretive buyback, by how much they were able to increase their EPS, and -for a given EPS forecast- which firms would have missed the EPS target without repurchasing. For example, say that analysts' EPS forecast for a certain firm is $\$ 4$ by the end of the quarter. For the same firm, we observe that the realized EPS is $\$ 4.1$ as announced at the end of the quarter. Thus, we check the number of shares held at the beginning of the period (say it was $N=1000$ millions), the number of shares repurchased (say $n=50$ millions) 
and at what price (say $P=\$ 50$ ). Hence we can build the foregone earnings due to buybacks as the opportunity cost of putting the amount $P n=2,500$ millions into a deposit with a quarterly rate of $r^{s}=5 \%$ at the net of taxes (e.g. $\tau=30 \%$ ). In our example, the forgone net earnings are equal to $\operatorname{Pnr}(1-\tau)=87.5$ millions. Under this manipulation, the realized earnings (as reported at the end of the quarter) are equal to $4.1 *(1000 M-50 M)=3,895$ millions such that - if managers were not buying back their own shares - the EPS before manipulation would have been equal to $(3,895 M+87.5 M) / 1000 M=3.98$ dollars per share. In this case, managers were able to beat the analysts' forecast by 10 cents by increasing the EPS from $3.98 \$$ to $4.1 \$$. In this sense, the repurchase program was accretive because managers were able to boost the EPS above the level of inaction by 12 cents.

On the left-hand side of Figure 2, we plot the frequency of firms conducting a repurchase over bins of EPS accretion, i.e. the difference between announced EPS and pre-repurchase EPS. As it is clear, more than $95 \%$ of firms conduct repurchases that allow to increase the EPS by 0 to 2 cents, and only few boost the EPS by more. This is because, as the numerical example suggests, trying to increase the EPS by more than 2 cents through buybacks might be extremely expensive and too detrimental for earnings such that the operation would be overall ineffective. Thereafter, we exploit the distance from the EPS forecast and the pre-repurchase EPS to understand which firms are more likely to repurchase and by how much.

The right-hand side of Figure 2 plots the share of repurchasing firms over the prerepurchase distance from the forecast target (normalized by the stock-price). If firms that were already on target exhibit an average probability of repurchasing around $4 \%$, things are different for those on the left of the cut-off. In fact, those are the firms strategically more willing to repurchase in order to correct the EPS and not disappoint capital markets, as documented in Hribar et al. (2006), Kasznik and McNichols (2002), Bartov et al. (2002). This explains why, on the left-hand side of the cut-off, the probability to repurchase increases the closer a firm is to meeting analysts expectations. In fact, for firms ex-ante closer to target, incentives to repurchase are high since it is easier and does not take much resources to tilt the EPS to meet market expectations. On the other hand, for firms far away from the cut-off, the probability to repurchase is smaller since any repurchase would not be large enough to put the EPS on target.

In light of this, we consider firms in the $[-0.02 \$ ;+0.02 \$]$ bracket and exploit this discontinuity to separate repurchasers and non-repurchasers and, to assess across both groups how exogenous changes in monetary policy affect repurchase expenditure through variations in the cost of debt. Thereafter, under this strategy, we will assess the causal effect of repurchase on real variables and study how repurchases and monetary policy interact. By doing so, we 
Fig. 2. EPS Accretion and Distance from Target
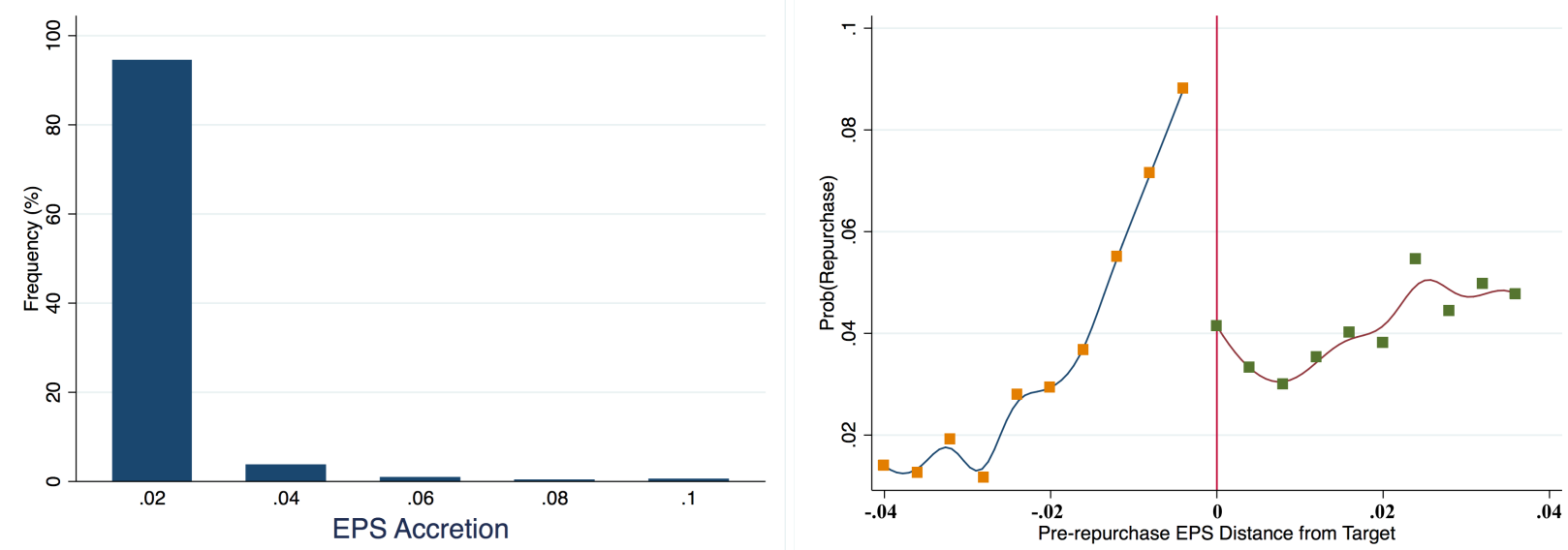

Notes: The graph on the left-hand side plots the frequency of repurchases by EPS accretion bins. The accretion is the difference between the manipulated EPS, i.e. the EPS as reported at the end of the quarter, and the EPS that would have prevailed if no buyback was conducted during the same quarter. The graph on the right-hand side plots the probability for a firm to buyback its own shares as a function of the distance of the pre-repurchase (non manipulated) EPS and the analysts EPS forecast (normalized by the end of the period stock price).

will be finally able to say by how much share buybacks attenuate the transmission of an accommodative monetary policy shock and by how much a accommodative monetary policy exacerbates the crowding-out effect of repurchases on real variables.

Table 5: Pre-repurchase Difference in Firm Characteristics

\begin{tabular}{ccccccc}
\hline \hline \multicolumn{1}{c}{$(1)$} & $(2)$ & $(3)$ & $(4)$ & $(5)$ & $(6)$ \\
& Leverage & Size & Yield & ROA & PE10 & Fin. Constraint \\
\hline \multirow{3}{*}{ Difference } & -1.360 & -0.009 & -0.412 & $0.004^{* * *}$ & -0.866 & -0.003 \\
& $(2.920)$ & $(0.039)$ & $(0.513)$ & $(0.000)$ & $(1.970)$ & $(0.004)$
\end{tabular}

Notes: The table reports the difference in characteristics between firms above and below the cut-off. Each difference is evaluated by regressing the firm characteristic on an indicator variable taking value one if the firm is below the cut-off. For each case, we control for time and firm's industry fixed effects. In model (1), the unit of interest Leverage is the ratio between the value of total corporate debt and equity. In model (2), the unit of interest Size is the logarithm of the total value of assets. In model (3), the unit of interest Yield is the yield for a 10-yearsmaturity corporate bond. In model (4), the unit of interest $R O A$ is the ratio of firm net income and assets in $t-4$. In model (5), the unit of interest $P E 10$ is the 10-quarter-moving-average of the price-earning ratio. In model (6), Fin. Constraint is a measure of the financial constraint of the firm built after Hadlock and Pierce (2010). Standard errors in parentheses, clustered at firm level. *, **, *** indicate significance at $1 \%, 5 \%$ and $10 \%$ level.

Yet, before proceeding in this direction, it is important to test whether firms around the discontinuity differ in major characteristics before the repurchase program is launched. This ensures that no other motive leads firms to repurchase their own share, but only the distance from the EPS forecast. Table 5 shows the difference in expected leverage, size, yield, profitability (ROA), PE10 and a measure of financial constraint (built following Hadlock and Pierce $(2010))$ between firms below $([-0.02 \$, 0))$ and above the cut-off $([0,0.02 \$])$. The only 
variable for which firms off-target are on average slightly significantly different is ROA, but the standard deviation of this variables in the sample is too small (16\%). Hence such statistically significant difference is not of concern. On the other hand, firms on and offtarget are homogeneous in all other dimensions: they are similarly leveraged, have similar size, cost of debt, growth perspectives and level of financial constraint the period before the EPS forecast is released. ${ }^{10}$

\subsection{Results}

Repurchase, EPS Distance from Forecast and the Cost of Debt Here we study how variations in the cost of debt due to innovations in monetary policy differently affect repurchasing behavior of firms around the discontinuity. First, for each firm we define the pre-repurchase distance from the EPS target with the variable Distance, i.e. the stock-price normalized difference between the pre-repurchase EPS and the EPS forecast. Under this definition, a firm $i$ is off (on) target before the repurchase if Distance $<0$ (Distance $\geq 0$ ). Second, given that most accretive repurchases result in an EPS accretion of 2 cents or less, we keep observations only for firms with Distance $_{i, t}$ in the $[-0.02 \$,+0.02 \$]$ bracket. Third, we extract the exogenous change in the firm-specific yield, by using monetary policy innovations (Shock) as instrument for the firm-specific cost of debt $(\Delta Y$ ield). Then, we study how being off-target and receiving an exogenous change in the cost of debt affects the level of repurchase. In order to do so, consider the following:

$$
\begin{aligned}
\text { Repurchases }_{i, t} & =\alpha_{1}+\beta_{1} \mathbb{I}\left(\text { Distance }_{i, t}<0\right)+\beta_{2} \widehat{\Delta Y \text { iel }} d_{i, t}+\beta_{3} \mathbb{I}\left(\text { Distance }_{i, t}<0\right) * \widehat{\Delta Y i e l} d_{i, t} \\
& +\beta_{4} \text { Distance }_{i, t}+\beta_{5} \mathbb{I}\left(\text { Distance }_{i, t}<0\right) * \text { Distance }_{i, t}+\beta_{6} \text { Distance }_{i, t}^{2} \\
& +\beta_{7} \mathbb{I}\left(\text { Distance }_{i, t}<0\right) * \text { Distance }_{i, t}^{2}+\beta_{8} \text { Distance }_{i, t}^{3} \\
& +\beta_{9} \mathbb{I}\left(\text { Distance }_{i, t}<0\right) * \text { Distance }_{i, t}^{3}+X_{i, t}^{\prime} \gamma+\theta_{t}+\epsilon_{i, t}
\end{aligned}
$$

where Repurchases $i, t$ is the level of positive net repurchase normalized by the level of assets in $t-4, \mathbb{I}\left(\right.$ Distance $\left._{i, t}<0\right)$ takes values 1 when the firm $i$ is off-target with respect to the analysts' EPS forecast, Distance $_{i, t}$ is the pre-repurchase distance from the forecast, the square and the cube of this measure and its interaction with $\mathbb{I}\left(\right.$ Distance $\left._{i, t}<0\right)$ control for non-linear behavior both at the left and right-hand side of the discontinuity cut-off, $\Delta \widehat{\text { Yield }}$ is the change in the 10-years corporate yield as predicted (instrumented) by monetary policy shocks, $X$ controls for the usual firm-level characteristics. We estimate this equation with

\footnotetext{
${ }^{10}$ In Appendix D, we show that the EPS forecast is not correlated with monetary policy or the firm-level exogenous variation in the cost of debt, neither in the quarter in which the EPS forecast is released, nor in the previous one.
} 
two-stage least squares (2SLS). ${ }^{11}$

Table 6 reports results. From column (1), firms that are off-target buyback $0.7 \%$ more than those already on target since they want to tilt the EPS to market expectations. In column (2), we control for the exogenous variation in the cost of debt due to monetary policy, but the effect is not significant across firms on both sides of the discontinuity, while the level of repurchase for firms off-target increases to 1\%. In column (3) we control for the interaction between the dummy variable $\mathbb{I}\left(\right.$ Distance $\left._{i, t}<0\right)$ and the change in the cost of debt $\widehat{\Delta Y i e l} d_{i, t}$. As a result, the average level of repurchase is now $2 \%$ higher for those off-target. More interesting is the effect of the cost of debt across groups: if the change in the yield does not matter for those already on target, it matters a lot for those off-target. In

Table 6: Repurchases, Distance from the EPS forecast and the Cost of Debt

\begin{tabular}{|c|c|c|c|c|c|}
\hline & $\begin{array}{c}(1) \\
\text { Rep. }\end{array}$ & $\begin{array}{c}(2) \\
\text { Rep. }\end{array}$ & $\begin{array}{c}(3) \\
\text { Rep. }\end{array}$ & $\begin{array}{c}(4) \\
\text { Rep. }\end{array}$ & $\begin{array}{c}(5) \\
\text { Rep. }\end{array}$ \\
\hline $\mathbb{I}($ Distance $<0)$ & $\begin{array}{c}0.007^{* * *} \\
(0.002)\end{array}$ & $\begin{array}{c}0.009^{* * *} \\
(0.002)\end{array}$ & $\begin{array}{c}0.021^{\text {*** }} \\
(0.005)\end{array}$ & $\begin{array}{c}0.015^{* * *} \\
(0.004)\end{array}$ & $\begin{array}{c}0.015^{* * *} \\
(0.004)\end{array}$ \\
\hline$\widehat{\Delta Y i e l d}$ & & $\begin{array}{c}0.000 \\
(0.001)\end{array}$ & $\begin{array}{c}0.003 \\
(0.002)\end{array}$ & $\begin{array}{c}0.002 \\
(0.002)\end{array}$ & $\begin{array}{c}0.002 \\
(0.001)\end{array}$ \\
\hline $\mathbb{I}($ Distance $<0) * \widehat{\Delta \text { Yield }}$ & & & $\begin{array}{c}-0.005^{* * *} \\
(0.001)\end{array}$ & $\begin{array}{c}-0.004^{* * *} \\
(0.001)\end{array}$ & $\begin{array}{c}-0.004^{* * *} \\
(0.001)\end{array}$ \\
\hline Observations & 44,856 & 31,263 & 31,263 & 31,263 & 30,494 \\
\hline Time FE & Yes & Yes & Yes & Yes & Yes \\
\hline Industry FE & No & No & No & Yes & Yes \\
\hline Controls (polynomial, $X$ ) & No & No & No & Yes & Yes \\
\hline Controls $(Z)$ & No & No & No & No & Yes \\
\hline Estimator & Ols & $2 \mathrm{sls}$ & $2 \mathrm{sls}$ & $2 \mathrm{sls}$ & $2 \mathrm{sls}$ \\
\hline
\end{tabular}

Notes: This table reports 2SLS estimates of equation (5). Standard errors in parentheses, clustered at firm level. For model (1) to (5), the unit of interest Repurchases is the difference between the value of stock purchases and stock issuances from the statement of cash flows. We consider only firms for which such difference is strictly positive and normalize it by total asset in $t-4 . \mathbb{I}($ Distance $<0)$ is an indicator variable that takes value one if the firm is below the EPS forecast before EPS manipulation. $\Delta \widehat{\text { Yield }}$ is the exogenous change in the 10-years corporate yield as predicted by monetary policy shocks, i.e. when we instrument $\Delta$ Yield with the monetary innovations Shock as from a SVAR. In column (4), we control for a polynomial of the variable Distance, i.e. the difference between the EPS forecast and the pre-manipulated EPS of the firm, interacted with the indicator $\mathbb{I}($ Distance $<0)$. $X$ controls for net income, normalized by total asset in $t-4$, Q-value of investment, a dummy indicating whether the firm has redistributed dividends in the first previous four quarters, a dummy indicating the quintile of asset the firms belong to. In column (5), we control for $Z$ : capital investment and employment, both normalized by total asset in $t-4 .^{*}, * *, * *$ indicate significance at $1 \%, 5 \%$ and $10 \%$ level.

\footnotetext{
${ }^{11}$ The initial stage for the instrumentation of the firm-level cost of debt with monetary policy innovations is reported in Appendix E.
} 
particular, if the cost of debt falls by $1 \%$, repurchases increase by $0.4 \%$ only for those that need to repurchase in the same quarter. In other words, if a firm in the position to launch an accretive repurchase faces an exogenous increase of the cost of debt, then its action will be limited and its capability to buyback a larger share of its assets will be reduced. Conversely, if the yield on debt falls for a firm about to launch an accretive repurchase, then the lower cost of debt expands the quantity repurchased. Therefore, we conclude that the cost of debt causally affects the size of a repurchase program and therefore it matters for those managers that need to buyback their own shares to satisfy market expectations. Column (4) shows results when controlling for a polynomial of the variable Distance and the indicator variable $\mathbb{I}($ Distance $<0)$. Results do not differ much. Finally, as robustness check, we want to be sure that the estimates of equation (5) are not biased by the feedback of the change in the corporate cost of debt on real variables. For this reasons, in column (5) we control also for the level of capital investment and employment both normalized by total asset in $t-4$. All coefficients remain the same, thus we can conclude that this instrumentation procedure allows us to establish the causal effect of an exogenous change of the corporate cost of debt on the level of repurchase and to provide an unbiased measure of such effect.

Real Variables, EPS Distance and the Cost of Debt Here we study how firms' investment and employment behavior are affected by the information shock and changes in the cost of debt as explained by monetary policy. To do so, consider the following:

$$
\begin{aligned}
\bar{Y}_{i,(t+1, t+4)}-\bar{Y}_{i,(t-4, t-1)}= & \alpha_{1}+\beta_{1} \mathbb{I}\left(\text { Distance }_{i, t}<0\right)+\beta_{2} \widehat{\Delta Y i e l} d_{i, t}+\beta_{3} \mathbb{I}\left(\text { Distance }_{i, t}<0\right) * \widehat{\Delta Y i e l} d_{i, t} \\
& +\beta_{4} \text { Distance }_{i, t}+\beta_{5} \mathbb{I}\left(\text { Distance }_{i, t}<0\right) * \text { Distance }_{i, t}+\beta_{6} \text { Distance }_{i, t}^{2} \\
& +\beta_{7} \mathbb{I}\left(\text { Distance }_{i, t}<0\right) * \text { Distance }_{i, t}^{2}+\beta_{8} \text { Distance }_{i, t}^{3} \\
& +\beta_{9} \mathbb{I}\left(\text { Distance }_{i, t}<0\right) * \text { Distance }_{i, t}^{3}+X_{i, t}^{\prime} \gamma+\theta_{t}+\epsilon_{i, t}
\end{aligned}
$$

where the dependent variable is the difference between the mean value of $Y$ in the next four quarters and in the previous four quarters, with $Y$ being either capital investment or employment. This difference is normalized by the level of assets in $t-4$. All dependent variables and controls are the same as in equation 5 .

Table 7 reports results. As from column (1), firms that are off-target and need to adjust the EPS forecast reduce investments by $0.25 \%$. When adding the instrumented change in the cost of debt $\Delta \widehat{\text { Yield }}$ and its interaction with the indicator $\mathbb{I}($ Distance $<0)$ in column (2), we find that a $1 \%$ fall in the cost of debt leads to a $0.13 \%$ increase of investments for "non-repurchasing" firms, i.e. those above the EPS target. On the other hand, the same fall in the cost of debt leads to a smaller increase in investments for "repurchasing" firms, which 
Table 7: Real variables, Distance from the EPS forecast and the Cost of Debt

\begin{tabular}{lcccc}
\hline \hline & $(1)$ & $(2)$ & $(3)$ & $(4)$ \\
& $\Delta I n v$. & $\Delta$ Inv. & $\Delta E m p$. & $\Delta E m p$. \\
\hline $\mathbb{I}($ Distance $<0)$ & & & & \\
& $-0.0025^{* * *}$ & $-0.0023^{* * *}$ & $-0.2720^{* * *}$ & $-0.3074^{* * *}$ \\
& $(0.0005)$ & $(0.0008)$ & $(0.0729)$ & $(0.1174)$ \\
$\widehat{\Delta \text { Yield }}$ & & & & \\
& & $-0.0013^{* *}$ & & $-0.0714^{* * *}$ \\
& & $(0.0006)$ & & $(0.0244)$ \\
$\mathbb{I}($ Distance $<0) * \widehat{\text { Yield }}$ & & $0.0004^{* *}$ & & $0.0120^{* *}$ \\
& & $(0.0002)$ & & $(0.0058)$ \\
& & & & \\
\hline Observations & 29,236 & 26,588 & 27,342 & 24,046 \\
Time FE & Yes & Yes & Yes & Yes \\
Industry FE & Yes & Yes & Yes & Yes \\
Controls $($ polynomial, $X)$ & Yes & Yes & Yes & Yes \\
Estimator & Ols & $2 \mathrm{sls}$ & Ols & $2 \mathrm{sls}$ \\
\hline \hline
\end{tabular}

Notes: This table reports 2SLS estimates of equation (6). Standard errors in parentheses, clustered at firm level. For model (1)-(2), the unit of interest $\Delta I n v$. is the difference between the mean value of capital investments in the next four quarters and in the previous four quarters, normalized by total asset in $t-4$. For model (3)-(4), the unit of interest $\Delta E m p$. is the difference between the mean level of employment in the next four quarters and in the previous four quarters, normalized by total asset in $t-4$. $\mathbb{I}($ Distance $<0)$ is an indicator variable that takes value one if the firm is below the EPS forecast before EPS manipulation. $\Delta \widehat{Y i e l d}$ is the exogenous change in the 10-years corporate yield as predicted by monetary policy shocks, i.e. when we instrument $\Delta Y$ ield with the monetary innovations Shock as from a SVAR. For both models, we control for a polynomial of the variable Distance, i.e. the difference between the EPS forecast and the pre-manipulated EPS of the firm, interacted with the indicator $\mathbb{I}($ Distance $<0)$. $X$ controls for net income, normalized by total asset in $t-4$, Q-value of investment, a dummy indicating whether the firm has redistributed dividends in the first previous four quarters, a dummy indicating the quintile of asset the firms belong to. ${ }^{* * *}, * * *$ indicate significance at $1 \%, 5 \%$ and $10 \%$ level.

is equal to $(0.13 \%-0.04 \%)=0.09 \%$. As from column (3), firms off-target cut employment by $27 \%$. When considering the cost of debt in column (4), we find that a $1 \%$ fall in the cost of debt leads to a $7.14 \%$ increase of employees for "non-repurchasing" firms. On the other hand, the same change in the cost of debt leads to a smaller increase in employees for "repurchasing" firms, which is equal to $(7.14 \%-1.20 \%)=5.94 \%$.

This evidence corroborates results from Table 6: the way firms on and off target manage a liquidity shock is very different. In fact, firms off-target, i.e "repurchasing" firms, exploit the lower cost of debt to buyback more and invest and hire less. On the contrary, "nonrepurchasing" firms do not use a lower cost of debt to buyback more shares, but invest and hire more. This proves that any unanticipated monetary policy shock that leads to a downward adjustment in the corporate cost of debt transmits to real variables in different ways, depending whether the firm is planning to repurchase its own shares or not. Hence, already from the results of Table 7 , we could state that the firm-level heterogeneity explained 
by the decision to conduct a share buyback attenuates the transmission of an accommodative monetary policy shock on real variables. In other words, for an exogenous fall in the cost of debt due to a monetary policy shock, the increase in investment and employment is smaller for "repurchasing" firms.

Real Variables, Repurchases and the Cost of Debt Here we complete our analysis by investigating the causal impact of share buybacks, changes in the cost of debt and their interaction on capital investments and employment. The following regression quantifies these three effects:

$$
\begin{aligned}
\bar{Y}_{i,(t+1, t+4)}-\bar{Y}_{i,(t-4, t-1)}= & \alpha_{1}+\beta_{1} \text { Repurchases }_{i, t}+\beta_{2} \Delta \text { Yield }_{i, t}+\beta_{3} \text { Repurchases }_{i, t} * \Delta \text { Yield }_{i, t} \\
& +\beta_{4} \text { Distance }_{i, t}+\beta_{5} \mathbb{I}\left(\text { Distance }_{i, t}<0\right) * \text { Distance }_{i, t}+\beta_{6} \text { Distance }_{i, t}^{2} \\
& +\beta_{7} \mathbb{I}\left(\text { Distance }_{i, t}<0\right) * \text { Distance }_{i, t}^{2}+\beta_{8} \text { Distance }_{i, t}^{3} \\
& +\beta_{9} \mathbb{I}\left(\text { Distance }_{i, t}<0\right) * \text { Distance }_{i, t}^{3}+X_{i, t}^{\prime} \gamma+\theta_{t}+\epsilon_{i, t} .
\end{aligned}
$$

Under this estimating equation, the parameter $\beta_{1}$ and $\beta_{3}$ will tell us respectively the local average treatment effect (LATE) of repurchase and changes in the cost of debt on real variables. The interaction of these two variables will explain whether variation in the cost of debt exacerbates the effect of repurchase on real variables $\left(\beta_{1}+\beta_{3}\right)$, and whether share repurchases reduce the effect of a change in the cost of debt on real variables $\left(\beta_{2}+\beta_{3}\right)$.

We estimate equation (6) using two-stage least squares (2SLS), where the endogenous variables Repurchases, $\Delta$ Yield and their interaction are instrumented respectively with the indicator variable $\mathbb{I}($ Distance $<0)$, the monetary policy innovation Shock, and the interaction of these two instruments. Table 8 shows results. As from column (1), we find that a $1 \%$ repurchase program leads to a $5.5 \%$ decline in investments. A $1 \%$ decrease in the corporate cost of debt works in the opposite direction and leads to an increase in investments by $0.27 \%$. However, launching a $1 \%$ repurchase program contemporaneously to a $1 \%$ fall of the cost of debt exacerbates the crowding-out of repurchase on investments $\left(\beta_{1}+\beta_{3}>\beta_{1}\right)$. At the same time, the same shock attenuates the positive effect of a lower cost of debt on investments $\left(\beta_{2}+\beta_{3}<\beta_{2}\right)$. When in column (2) we repeat out estimation under further controls, we find similar results. As from column (3), a $1 \%$ repurchase program leads to a decline in the employment stock by 1.2 units per million of assets. On the other hand, $1 \%$ decrease in the corporate cost of debt causes an increase in employment by 0.05 units per million of assets. Also in this case, launching a 1\% repurchase program contemporaneously to a $1 \%$ fall of the cost of debt exacerbates the crowding-out of repurchase on employment and - at the same time - it attenuates the positive effect of a lower cost of debt on this 
variable. Adding further controls in column (4) does not change significantly these results.

In light of this evidence, we conclude that a fall in the cost of debt does exacerbate the crowding-out effect of repurchase on real variables. Moreover, the repurchase channel attenuates the positive effect that a decline in the cost of debt has on investments and employment. ${ }^{12}$

Table 8: Real variables, Repurchases and the Cost of Debt

\begin{tabular}{|c|c|c|c|c|}
\hline & $\begin{array}{c}(1) \\
\Delta I n v .\end{array}$ & $\begin{array}{c}(2) \\
\Delta I n v .\end{array}$ & $\begin{array}{c}(3) \\
\Delta E m p .\end{array}$ & $\begin{array}{c}(4) \\
\Delta E m p .\end{array}$ \\
\hline Repurchase & $\begin{array}{c}-0.0557^{* * *} \\
(0.0193)\end{array}$ & $\begin{array}{c}-0.0574^{* * *} \\
(0.0200)\end{array}$ & $\begin{array}{c}-1.2083^{* *} \\
(0.5248)\end{array}$ & $\begin{array}{c}-1.3652^{* * *} \\
(0.5244)\end{array}$ \\
\hline$\Delta Y$ ield & $\begin{array}{c}-0.0027^{* *} \\
(0.0012)\end{array}$ & $\begin{array}{c}-0.0026^{* *} \\
(0.0012)\end{array}$ & $\begin{array}{c}-0.0512^{* *} \\
(0.0207)\end{array}$ & $\begin{array}{c}-0.0491^{* *} \\
(0.0201)\end{array}$ \\
\hline Repurchase $* \Delta$ Yield & $\begin{array}{l}0.0255^{* *} \\
(0.0112)\end{array}$ & $\begin{array}{l}0.0281^{* *} \\
(0.0120)\end{array}$ & $\begin{array}{l}0.2419^{*} \\
(0.1429)\end{array}$ & $\begin{array}{l}0.2438^{*} \\
(0.1471)\end{array}$ \\
\hline Observations & 26,588 & 26,588 & 24,046 & 24,046 \\
\hline Time FE & Yes & Yes & Yes & Yes \\
\hline Industry FE & Yes & Yes & Yes & Yes \\
\hline Controls (polynomial, $X$ ) & No & Yes & No & Yes \\
\hline Estimator & 2 sls & 2 sls & $2 \mathrm{sls}$ & $2 \mathrm{sls}$ \\
\hline
\end{tabular}

Notes: This table reports 2SLS estimates of equation 7. Standard errors in parentheses, clustered at firm level. For model (1)-(2), the unit of interest $\Delta I n v$. is the difference between the mean value of capital investments in the next four quarters and in the previous four quarters, normalized by total asset in $t-4$. For model (3)-(4), the unit of interest $\Delta E m p$. is the difference between the mean level of employment in the next four quarters and in the previous four quarters, normalized by total asset in $t-4$. Repurchases is the difference between the value of stock purchases and stock issuances from the statement of cash flows. We consider only firms for which such difference is positive, and we normalize it by total asset in $t-4$. The endogenous variables Repurchases, $\Delta Y$ ield and their interaction are instrumented respectively with the indicator variable $\mathbb{I}($ Distance $<0)$, the monetary policy innovation Shock, and the interaction of the two. We control for a polynomial of the variable Distance, i.e. the difference between the EPS forecast and the pre-manipulated EPS of the firm, interacted with the indicator $\mathbb{I}($ Distance $<0)$. Control $X$ includes net income normalized by total assets in $t-4$, Q-value of investment, a dummy indicating whether the firm has redistributed dividends in the first previous four quarters, a dummy indicating the quintile of asset the firms belong to. ${ }^{*}, * *, * * *$ indicate significance at $1 \%, 5 \%$ and $10 \%$ level.

\footnotetext{
${ }^{12}$ In Appendix F, we show that results do not change much when using directly monetary policy shocks in equation (7), instead of the corporate cost of debt. The difference between the results following this alternative identification and the ones from Table 8 is explained by firm-level heterogeneity in the cost of debt and fundamentals. We believe that - by considering the firm-level cost of debt as in equation (7) we do a better job in measuring the firm-level effect of an exogenous monetary policy innovation on the managerial incentive to buyback.
} 


\subsection{The attenuation of accommodative monetary policy on real variables due to repurchases}

By how much do repurchases reduce the transmission of an accommodative monetary policy shock on real variables? Here we compute a back-of-the-envelope calculation by using results from Section 3.3 and 4.2. From Table 4 column (2), we know that a 1\% exogenous innovation in the fund rate leads to a $0.62 \%$ increase of the 10-years yield. As from Table 6 column (4), we know that a $0.62 \%$ increase in the yield leads to a rise in repurchase by $0.44 \times 0.62=0.27 \%$. Therefore, by using results from Table 8 , we can write the expected change in real variables for a $1 \%$ accommodative monetary policy shock and its implied repurchase level equal to $0.27 \%$ as follows:

$\mathbb{E}\left[\Delta\right.$ Inv. $\mid$ Shock $k_{t}=-1 \%$, Rep $\left.=0.27 \%\right]=-5.57 \times 0.27 \%+0.27 \times(0.62 \%)-2.55 \times 0.27 \% \approx 0.15$

$\mathbb{E}\left[\Delta\right.$ Emp. $\mid$ Shock $_{t}=-1 \%$, Rep $\left.=0.27 \%\right]=-120.83 \times 0.27 \%+5.12 \times(0.62 \%)-24.19 \times 0.27 \%$ $\approx 2.75$

In words, the overall effect of an expansionary monetary policy is positive an in line with what the basic macroeconomic theory predicts: investments grow by 150 thousands dollars every million of assets and employment grows by 2.75 employees every million of assets. Yet, if we mute the repurchase channel, the transmission of monetary policy is going to be stronger. In fact, the expected change in real variables for a $1 \%$ accommodative monetary policy shock and a repurchase level equal to zero is:

$$
\begin{gathered}
\mathbb{E}\left[\Delta \text { Inv. } \mid \text { Shock }_{t}=-1 \%, \operatorname{Rep}=0 \%\right]=0.27 \times(0.62 \%) \approx 0.17 \\
\mathbb{E}\left[\Delta \text { Emp. } \mid \text { Shock }_{t}=-1 \%, \text { Rep }=0 \%\right]=5.12 \times(0.62 \%) \approx 3.18 .
\end{gathered}
$$

meaning that - if the repurchase channel is muted - a $1 \%$ accommodative monetary policy shock would increase investments by 170 thousands dollars every million of assets and employment by 3.18 units every million of assets. Therefore, in light of this simple backof-the envelope calculation, we can say that the repurchase channel attenuates the transmission of a $1 \%$ accommodative shocks on investments and employment respectively by $[1-(0.15 / 0.17)]=11 \%$ and $[1-(2.75 / 3.18)]=14 \%$.

In light of these results, we conclude that share buybacks not only crowd-out investments and employment, but also they represent a channel through which the transmission of an 
accommodative monetary policy shock is attenuated and the crowding-out effect on real variables exacerbated. This happens because firms that do repurchase exploit the lower cost of debt to finance these non-productive operations. As a consequence, they divert resources from the real economy.

\section{Robustness Checks}

\subsection{Pre-existing differences across firms above and below the EPS target}

In order to validate our identification strategy, we need to check that there are no other discontinuous differences in firms' dynamics around the pre-repurchase EPS cut-off. A common way to confirm this assumption is to test whether firms around the cut-off exhibit pre-existing differences in capital investments and employment choices, i.e. if changes in the dependent variables for periods prior to the repurchase differ across firms below or above target. We carryout this exercise for the four preceding $\mathrm{j}$ quarters by running the following regression for firms with Distance $_{i, t}$ in the $[-0.02 \$,+0.02 \$]$ :

$$
\Delta Y_{i,(t-1, t-j)}=\alpha+\beta \mathbb{I}\left(\text { Distance }_{i, t}<0\right)+\theta_{t}+\epsilon_{i, t}
$$

where $\Delta Y_{i,(t-1, t-j)}$ is the dependent variable simple difference between $t-1$ and $t-j$, with $j=\{1,2,3,4\}$. As from Table 9 , there are no systematic pre-existing differences between firms at the left and at the right of the discontinuity in terms of outcome variables: the pre-repurchase common trend assumption holds and our identification strategy is valid and the results from Section 4.2 can be interpreted in a causal way.

\subsection{The financing of share buybacks around the EPS target}

In this section, we check if indeed firms off-target use debt to repurchase compared with firms on target. In order to do so, we propose the same accounting equation as in Section 3.2. Columns 1 and 2 of Table 10 show the contribution of debt to repurchase for the sample of firms off-target (whose distance from target is in the $[-0.02 \$, 0 \$$ ) bracket) while column 3 and 4 show results for firms on target (whose distance from target is in the $[0 \$,+0.02 \$]$ ). For firms off-target, every dollar of assets repurchased is financed with 20 cents coming from new debt issuance (column (1)); when controlling for other sources of financing and expenditures (column (2)), the result does not change. For firms already on target (column (3) and (4)), the contribution of debt is not significant. As we learned from Section 4.2, firms below and

above target manage their resources in different ways: the former devote more resources to 
Table 9: Pre-repurchase Trend in Outcome Variables

\begin{tabular}{lcc}
\hline \hline & $(1)$ & $(2)$ \\
& $\Delta$ Investment & $\Delta$ Employment \\
\hline $\begin{array}{l}\text { Changes }(t-2 \text { to } t-1) \\
\mathbb{I}(\text { Distance }<0)\end{array}$ & -0.000 & $0.000^{*}$ \\
& $(0.000)$ & $(0.000)$ \\
Changes $(t-3$ to $t-1)$ & & \\
$\mathbb{I}($ Distance $<0)$ & $-0.001^{*}$ & 0.000 \\
& $(0.000)$ & $(0.000)$ \\
Changes $(t-4$ to $t-1)$ & & \\
$\mathbb{I}($ Distance $<0)$ & -0.001 & 0.000 \\
& $(0.001)$ & $(0.000)$ \\
Changes $(t-5$ to $t-1)$ & & \\
$\mathbb{I}($ Distance $<0)$ & -0.000 & 0.000 \\
& $(0.003)$ & $(0.000)$ \\
& & \\
\hline Time FE & Yes & Yes \\
Industry FE & Yes & Yes \\
Controls $(X)$ & No & No \\
\hline
\end{tabular}

Notes: Standard errors in parentheses, clustered at firm level. For model (1), the unit of interest $\Delta I n v$. is the difference between the mean value of capital investments in the four quarters previous to the repurchase and four quarters $j=\{2,3,4,5\}$ periods before the repurchase. Each difference is normalized by total asset in $t-4$. For model (2) the unit of interest $\Delta I n v$. is the difference between the mean level of employment in the four quarters previous to the repurchase and four quarters $j=\{2,3,4,5\}$ periods before the repurchase. Each difference is normalized by total asset in $t-4$. $\mathbb{I}($ Distance $<0)$ is an indicator variable taking value one if the firm is currently below the EPS target. $*, * *, * * *$ indicate significance at $1 \%, 5 \%$ and $10 \%$ level.

repurchase rather than investing in new capital and new hires, whereas the latter use their resources for productive purposes. This validates our analysis, confirming that debt is an important source for firms that need to launch an accretive repurchase to bring the EPS on target. Firms already on target do not use debt issuance to finance repurchases, but they use it - along with other financial resources - to fund new investment and employment.

\subsection{EPS accretion and monetary policy}

The model of Section 2 shows that a fall in the cost of debt allows to boost the EPS through an accretive repurchase. Here we want to test in the data if this is true and by how much an exogenous monetary policy innovation affects the capability of managers to conduct a accretive repurchase, i.e. a repurchase that is able to increase the EPS. In order 
Table 10: Financing Buybacks

\begin{tabular}{lcccc}
\hline \hline & $(1)$ & $(2)$ & $(3)$ & $(4)$ \\
& Repurchase & Repurchase & Repurchase & Repurchase \\
\hline Debt & & & & \\
& $0.20^{*}$ & $0.20^{* *}$ & 0.00 & 0.01 \\
& $(0.12)$ & $(0.10)$ & $(0.00)$ & $(0.03)$ \\
\hline Observations & 21,422 & 15,851 & 20,348 & 17,392 \\
Off Target Sample & Yes & Yes & No & No \\
Time FE & No & No & No & No \\
Industry FE & No & No & No & No \\
Controls (Other sources) & No & Yes & No & Yes \\
\hline \hline
\end{tabular}

Notes: Standard errors in parentheses, clustered at firm level. For model (1) to (4), the unit of interest Repurchases is the difference between the value of stock purchases and stock issuances from the statement of cash flows. We consider only firms for which such difference is positive, and we normalize it by total asset in $t-4$. normalized by total asset in $t-4$. $\Delta D e b t$ is the change in the value of current total debt of the firm, normalized by total asset in $t-4$. When used, the control variables are all main other sources of the budget constraint of the firm: the change in firm money holding plus current net profit, capital expenditure and the value of the dividends payed. $*$, **,*** indicate significance at $1 \%, 5 \%$ and $10 \%$ level.

Table 11: EPS Accretion and Monetary Policy Shocks

\begin{tabular}{lcccc}
\hline \hline & $(1)$ & $(2)$ & $(3)$ & $(4)$ \\
& $\mathbb{I}($ Accretion $>0)$ & $\mathbb{I}($ Accretion $>0)$ & Accretion & Accretion \\
\hline \multirow{3}{*}{ Shock } & $-0.207^{* * *}$ & $-0.216^{* * *}$ & $-0.002^{* * *}$ & $-0.002^{* * *}$ \\
& $(0.010)$ & $(0.011)$ & $(0.000)$ & $(0.000)$ \\
& & & & \\
\hline Observations & 44,856 & 39,431 & 44,856 & 39,431 \\
Time FE & Yes & Yes & Yes & Yes \\
Industry FE & Yes & Yes & Yes & Yes \\
Controls $(X)$ & Yes & Yes & Yes & Yes \\
Controls $(Z)$ & No & Yes & No & Yes \\
\hline \hline
\end{tabular}

Notes: Standard errors in parentheses, clustered at firm level. In model (1) and (2), the unit of observation is $\mathbb{I}($ Accretion $>0)$, an indicator variable taking value one if the firm is was able to boot the EPS through a repurchase program, i.e. if the difference between reported EPS and the EPS that would have prevailed without repurchasing is positive. In model (3) and 4, the unit of observation Accretion is the difference between reported EPS and the EPS that would have prevailed without repurchasing. Shock is an exogenous monetary innovation as from a SVAR (see Appendix A for details). Controls includes net income, normalized by total asset in $t-4$, Q-value of investment, a dummy indicating whether the firm has redistributed dividends in the first previous four quarters, a dummy indicating the quintile of asset the firms belong to. $Z$ controls for the level of capital expenditure and the stock of employment, both normalized by total asset in $t-4$. *, $* *, * * *$ indicate significance at $1 \%, 5 \%$ and $10 \%$ level.

to test it, consider the

$$
\begin{gathered}
\mathbb{I}\left(\text { Acretion }_{i, t}>0\right)=\alpha+\beta \text { Shock }_{t}+X_{i, t}^{\prime} \gamma+Z_{i, t}^{\prime} \mu+\theta_{t}+\epsilon_{i, t} \\
\text { Accretion }_{i, t}=\alpha+\beta \text { Shock }_{t}+X_{i, t}^{\prime} \gamma+Z_{i, t}^{\prime} \mu+\theta_{t}+\epsilon_{i, t}
\end{gathered}
$$


where $\mathbb{I}($ Accretion $>0)$ is an indicator variable taking value one if the firm was able to increase the EPS over the quarter through a share repurchase, Accretion is the pricenormalized difference between the reported EPS at the end of the quarter and the one that would have prevailed without launching a repurchase program. As in Section 3.3 we control for firms fundamentals $(X)$ and real variables $(Z)$. Table 11 shows results. As from column (1), a $1 \%$ fall in the Fed fund rate leads to an increase in the (linear) probability of conducting an accretive repurchase of $21 \%$. The same estimate holds when controlling for real variables as in column (2). In column (3) we consider the level of accretion, and we find that a $1 \%$ fall in the Fed fund rate leads to an increase in accretion by 0.2 cents. This result is robust also when controlling for real variables, as in column (4).

To sum up, the theoretical intuition of the model remains true: for an accommodative monetary policy shock, a firm is able to boost the EPS through higher repurchase. In other words, accommodative monetary policy helps managers to boost the EPS through the repurchase channel.

\section{Conclusion}

This paper documents how debt and the cost of debt are key deciding factors for a manager when launching a repurchase program. In particular, we show that if a firm benefits from an exogenous fall in the corporate yield - caused by an accommodative monetary policy shock - and needs to buyback its shares, the amount of shares repurchased from the stock market is going to be larger. This proves that the cost of debt determines the size of repurchase programs and that firms mostly rely on new and low-cost debt to finance this market operation. Moreover, when conducting a repurchase of their shares, the same firms tend to reduce investment and employment since they devote their resources to these programs at the expense of new capital or employees. We, thus, conclude that share buybacks represent a channel through which the transmission of an accommodative monetary policy shock is attenuated.

The main contribution of the paper is that we are able to measure the causal impact of monetary policy on share buyback programmes, to quantify by how much the crowding-out effect of repurchases on investment and employment is due to an accommodative monetary policy shock, and - finally - to assess by how much share buybacks reduce the effectiveness of an expansionary monetary policy. This is an empirical challenge that we solve by exploiting a discontinuity in the data triggered by managerial consideration over the EPS index. We use an information shock based on the distance of a firm's EPS from the analysts' forecast to split the sample in firms more prone to buyback their own shares, i.e. those below the analyst EPS 
forecast, and those that are less prone to buyback, i.e. those above the forecast. Then we show that a negative change in the cost of debt - as explained by an accommodative monetary policy shock - affects only managers below the target and allows them to launch a larger repurchase program and to easily adjust their EPS in order to meet market expectations. Through this instrumentation, we show that such repurchase behavior has a causal and negative impact on investments and employment and that an expansionary monetary policy exacerbates this effect such that the overall transmission of an accommodative shock on real variables is attenuated. In particular we find that, if the repurchase channel was muted, the transmission of a $1 \%$ accommodative shock on investments and employment would be respectively $11 \%$ and $14 \%$ stronger. 


\section{References}

Acharya, V. V., Almeida, H., Campello, M., 2013. Aggregate risk and the choice between cash and lines of credit. The Journal of Finance 68, 2059-2116.

Almeida, H., Fos, V., Kronlund, M., 2016. The real effects of share repurchases. Journal of Financial Economics 119, 168-185.

Armenter, R., Hnatkovska, V., 2011. The macroeconomics of firms' savings .

Babenko, I., 2009. Share repurchases and pay-performance sensitivity of employee compensation contracts. The Journal of Finance 64, 117-150.

Bacchetta, P., Benhima, K., Poilly, C., 2014. Corporate cash and employment. American Economic Journal: Macroeconomics .

Baker, M., Wurgler, J., 2002. Market timing and capital structure. The journal of finance $57,1-32$.

Bartov, E., Givoly, D., Hayn, C., 2002. The rewards to meeting or beating earnings expectations. Journal of accounting and economics 33, 173-204.

Bens, D. A., Nagar, V., Skinner, D. J., Wong, M. F., 2003. Employee stock options, eps dilution, and stock repurchases. Journal of Accounting and Economics 36, 51-90.

Bloom, N., Bond, S., Van Reenen, J., 2007. Uncertainty and investment dynamics. The review of economic studies 74, 391-415.

Brockman, P., Chung, D. Y., 2001. Managerial timing and corporate liquidity:: evidence from actual share repurchases. Journal of Financial Economics 61, 417-448.

Burgstahler, D., Dichev, I., 1997. Earnings management to avoid earnings decreases and losses. Journal of accounting and economics 24, 99-126.

Burgstahler, D., Eames, M., 2006. Management of earnings and analysts' forecasts to achieve zero and small positive earnings surprises. Journal of Business Finance \& Accounting 33, 633-652.

DeFond, M., Park, C., 2000. Earnings surprises expressed in cents per share: stock price effects and implications for accruals management. Tech. rep., Working paper, Leventhal School of Accounting, University of Southern California. 
Degeorge, F., Patel, J., Zeckhauser, R., 1999. Earnings management to exceed thresholds. The Journal of Business 72, 1-33.

Dittmar, A. K., 2000. Why do firms repurchase stock. The Journal of Business 73, 331-355.

Falato, A., Kadyrzhanova, D., Sim, J., 2013. Rising intangible capital, shrinking debt capacity, and the us corporate savings glut .

Gertler, M., Karadi, P., 2015. Monetary policy surprises, credit costs, and economic activity. American Economic Journal: Macroeconomics 7, 44-76.

Graham, J. R., Harvey, C. R., 2005. The long-run equity risk premium. Finance Research Letters 2, 185-194.

Grullon, G., Ikenberry, D. L., 2000. What do we know about stock repurchases? Journal of Applied Corporate Finance 13, 31-51.

Grullon, G., Michaely, R., 2004. The information content of share repurchase programs. The Journal of Finance 59, 651-680.

Hadlock, C. J., Pierce, J. R., 2010. New evidence on measuring financial constraints: Moving beyond the kz index. The Review of Financial Studies 23, 1909-1940.

Hribar, P., Jenkins, N. T., Johnson, W. B., 2006. Stock repurchases as an earnings management device. Journal of Accounting and Economics 41, 3-27.

Ikenberry, D., Lakonishok, J., Vermaelen, T., 1995. Market underreaction to open market share repurchases. Journal of financial economics 39, 181-208.

Jeenas, P., 2018. Monetary policy shocks, financial structure, and firm activity: A panel approach .

Kahle, K. M., 2002. When a buyback isnta buyback: Open market repurchases and employee options. Journal of Financial Economics 63, 235-261.

Kasznik, R., McNichols, M. F., 2002. Does meeting earnings expectations matter? evidence from analyst forecast revisions and share prices. Journal of Accounting research 40, 727759.

Kinney, W., Burgstahler, D., Martin, R., 2002. Earnings surprise materiality as measured by stock returns. Journal of Accounting Research 40, 1297-1329.

Lazonick, W., 2014. Profits without prosperity. Harvard Business Review 92, 46-55. 
Ma, Y., 2014. Nonfinancial firms as arbitrageurs in their own securities. Tech. rep., Working Paper.

Melcangi, D., 2017. The marginal propensity to hire .

Ottonello, P., Winberry, T., 2018. Financial heterogeneity and the investment channel of monetary policy. Tech. rep., National Bureau of Economic Research.

Peyer, U., Vermaelen, T., 2008. The nature and persistence of buyback anomalies. The Review of Financial Studies 22, 1693-1745.

Ramey, V. A., 2009. Defense news shocks, 1939-2008: Estimates based on news sources. Unpublished paper, University of California, San Diego .

Ramey, V. A., 2016. Macroeconomic shocks and their propagation. Handbook of Macroeconomics 2, 71-162.

Rossi, B., Zubairy, S., 2011. What is the importance of monetary and fiscal shocks in explaining us macroeconomic fluctuations? Journal of Money, Credit and Banking 43, 1247-1270.

Skinner, D. J., Sloan, R. G., 2002. Earnings surprises, growth expectations, and stock returns or don't let an earnings torpedo sink your portfolio. Review of accounting studies 7, 289312.

Stein, J. C., 1996. Rational capital budgeting in an irrational world. Tech. rep., National bureau of economic research.

Vermaelen, T., 1981. Common stock repurchases and market signalling: An empirical study. Journal of financial economics 9, 139-183. 


\section{Appendix A. A SVAR for Monetary Shocks}

We follow Ramey (2016) and Rossi and Zubairy (2011) to extract monetary policy shocks from a SVAR. In particular, for a time-window spanning from 1985q1 to 2016q4, we consider this model:

$$
Z_{t}=K+\Gamma_{1}(t)+\Gamma_{2}(t) d_{t}+A(L) Z_{t-1}+B(L) u_{t}^{R}+\epsilon_{t}
$$

where $Z_{t}=\left[G_{t}, Y_{t}, h_{t}, C_{t}, I_{t}, w_{t}, \pi_{t}, r_{t}\right]$, i.e. a vector containing series for government spending $\left(G_{t}\right)$, real GDP $\left(Y_{t}\right)$, hours worked in the non-farm business sector $\left(h_{t}\right)$, non-durable and service consumption $\left(C_{t}\right)$, gross private investments and durable consumption $\left(I_{t}\right)$, wages in the non-farm business sector $\left(w_{t}\right)$, GDP deflator inflation $\left(\pi_{t}\right)$ and the 3-months rate on government bonds. $\Gamma_{1}(t)$ and $\Gamma_{2}(t)$ are both a fourth-degree polynomial time trend, $d_{t}$ is a dummy variable taking value equal to one for periods after the beginning of the great recession (2008q1-2016q4), and zero otherwise. In this way, not only we control for non-linear trend, but also we take into account the structural change occurred to the economy with the great recession. Moreover, with $u^{R}$ we include also a "narrative" measure of government spending shocks, based on defense news-shocks as from Ramey (2009). $A(L)$ and $B(L)$ are set to be lag polynomials of degree four, consistently with the existing literature on fiscal a monetary policy shocks. All variables, with the exception of the interest rate, are in logs. The monetary shocks are identified using a Cholesky decomposition.

\section{Appendix B. Proof of Proposition 1}

Assume for simplicity that the tax rate is zero (i.e. $\tau=0$ ). Then, consider the system of equation pinned down by condition (i) and (ii) of Proposition 1 and evaluate it at the equilibrium:

$$
\left\{\begin{array}{l}
{\left[f^{\prime}\left(B^{*}-n^{*} P\right)-r^{B}\right]=\theta(1-d)\left[B^{*}(1-d)+d n^{*} P\right]\left(N-n^{*}\right)} \\
E P S\left(B^{*}, n^{*}\right)=P\left[f^{\prime}+r^{s}\right]+\theta d\left[(1-d) B^{*}+d n^{*} P\right] P\left(N-n^{*}\right)
\end{array}\right.
$$

Perturbate the latter for a small change in the interest rate $r^{s}$. Then we obtain the following

$$
\left\{\begin{array}{l}
a \frac{\partial B^{*}}{\partial r^{s}}+b \frac{\partial n^{*}}{\partial r^{s}}=\kappa \\
c \frac{\partial B^{*}}{\partial r^{s}}+d \frac{\partial n^{*}}{\partial r^{s}}=\frac{\kappa B^{*}+N P}{N-n^{*}}
\end{array}\right.
$$


where

$$
\begin{aligned}
& a=\left[f^{\prime \prime}-\theta(1-d)^{2}\left(N-n^{*}\right)\right] \\
& b=\theta(1-d)\left[B^{*}(1-d)-d P\left(N-2 n^{*}\right)\right]-P f^{\prime \prime} \\
& c=-\frac{P f^{\prime \prime}}{N-n^{*}}-\theta d P(1-d)\left(N-n^{*}\right) \\
& d=f^{\prime \prime} P^{2}-\theta d P\left[d P\left(N-2 n^{*}\right)-(1-d) B^{*}\right] .
\end{aligned}
$$

Then, by using Cramer Rule, we can find the solution of system (B.1):

$$
\begin{aligned}
\frac{\partial B^{*}}{\partial r^{s}} & =\frac{\kappa d-b \frac{\kappa B^{*}+N P}{N-n^{*}}}{a d-c b} \\
\frac{\partial n^{*}}{\partial r^{s}} & =\frac{a \frac{\kappa B^{*}+N P}{N-n^{*}}-\kappa c}{a d-c b}
\end{aligned}
$$

To understand the sign of $\frac{\partial B^{*}}{\partial r^{s}}$ and $\frac{\partial n^{*}}{\partial r^{s}}$, analyze first the sign of the denominator. For simplicity, we consider the case in which $\theta=0$. Therefore we can write:

$$
a d-c b=\frac{\left(f^{\prime \prime}\right)^{2} P^{2}\left[N-n^{*}-1\right]}{N-n^{*}} .
$$

Assuming concavity of the production function $(\alpha \in(0,1)), N-n^{*}>1$ and $\theta$ small is sufficient for $a d-c b$ to be positive. Under these normative assumptions, which respectively imply decreasing returns to capital, an amount of outstanding shares bigger than 1, and low cost in leverage change, we can write

$$
\kappa d-b \frac{\kappa B^{*}+N P}{N-n^{*}}<0
$$

and

$$
a \frac{\kappa B^{*}+N P}{N-n^{*}}-\kappa c<0
$$

Therefore, under these normative assumptions, we conclude that 


$$
\begin{aligned}
& \frac{\partial B^{*}}{\partial r^{s}}<0 \\
& \frac{\partial n^{*}}{\partial r^{s}}<0 . \square
\end{aligned}
$$

\section{Appendix C. The Financing of Share Buybacks}

In Section 3.2, we show that newly issued debt is mostly used to finance buyback programs. Here we corroborate this idea by considering this specification:

$\Delta$ Debt $_{i,(t, t-1)}=\beta_{1}$ Repurchases $_{i, t}+\beta_{2} \Delta$ Money $_{i, t}+\beta_{3}$ Profits $_{i, t}+\beta_{3}$ Investment $_{i, t}+\beta_{4}$ Dividends $_{i, t}+\epsilon_{i, t}$

Differently, from the specification used in Section 3.2, here the dependent variable is the change in the amount of debt $(\Delta D e b t)$. Moreover, instead of considering changes in cashholdings and newly generated profits under the same variable, here we consider this two subvoices separately: $\Delta$ Money captures the change in cash holdings between two consecutive periods, whereas Profits captures the amount of net profits generated in the current quarter. All variables are normalized by assets in $t-4$. Results are shown in Table C.1. As from column (1), one dollar of equity repurchase explains an increase in newly debt issuance by 26 cents; for every dollar of new capital investments, debt issuance increase by 49 cents. This result does not change when controlling for time fixed effects (column (2)). When considering only firms with Repurchases $>0$ - i.e. they are always buying back more shares than the number of shares issued - as in column (3) and (4), the result is almost the same.

To conclude our analysis, we now consider again the same specification of Section 3.2, but variables in levels and both cash-holdings and profits on the right-hand side:

Repurchases $_{i, t}=\beta_{1} \Delta$ Debt $_{i,(t, t-1)}+\beta_{2} \Delta$ Money $_{i, t}+\beta_{3}$ Profits $_{i, t}+\beta_{3}$ Investment $_{i, t}+\beta_{4}$ Dividends $_{i, t}+\epsilon_{i, t}$.

Table C.2 reports results. As from column (1), each dollar spent in repurchase is financed with 34 cents of newly issued debt, 12 cents from cash holdings, 35 cents from profits, 23 cents from a reduction of investments. These magnitudes does not change when controlling for time fixed effects (column (2)). When considering only "net-repurchasers" (column (3) and $(4)$, the contribution of debt does not change whereas the contribution of profits in the 
Table C.1: Financing Buybacks (1)

\begin{tabular}{|c|c|c|c|c|}
\hline & $\begin{array}{c}(1) \\
\Delta D e b t\end{array}$ & $\begin{array}{c}(2) \\
\Delta D e b t\end{array}$ & $\begin{array}{c}(3) \\
\Delta D e b t\end{array}$ & $\begin{array}{c}(4) \\
\Delta D e b t\end{array}$ \\
\hline Repurchases & $\begin{array}{c}0.26^{* * *} \\
(0.04)\end{array}$ & $\begin{array}{c}0.25^{* * *} \\
(0.04)\end{array}$ & $\begin{array}{c}0.22^{* * *} \\
(0.04)\end{array}$ & $\begin{array}{c}0.22^{* * *} \\
(0.04)\end{array}$ \\
\hline$\Delta$ Money & $\begin{array}{c}0.07 \\
(0.05)\end{array}$ & $\begin{array}{c}0.07 \\
(0.05)\end{array}$ & $\begin{array}{l}0.12^{* *} \\
(0.05)\end{array}$ & $\begin{array}{l}0.12^{* *} \\
(0.05)\end{array}$ \\
\hline Profits & $\begin{array}{c}-0.16^{\text {*** }} \\
(0.03)\end{array}$ & $\begin{array}{c}-0.15^{* * *} \\
(0.03)\end{array}$ & $\begin{array}{c}-0.11^{\text {*** }} \\
(0.04)\end{array}$ & $\begin{array}{c}-0.11^{\text {*** }} \\
(0.04)\end{array}$ \\
\hline Investments & $\begin{array}{c}0.49^{* * *} \\
(0.06)\end{array}$ & $\begin{array}{c}0.49^{* * *} \\
(0.06)\end{array}$ & $\begin{array}{c}0.44^{* * *} \\
(0.06)\end{array}$ & $\begin{array}{c}0.44^{* * *} \\
(0.06)\end{array}$ \\
\hline Dividends & $\begin{array}{c}0.03^{* * *} \\
(0.01)\end{array}$ & $\begin{array}{c}0.03^{* * *} \\
(0.01)\end{array}$ & $\begin{array}{l}0.03^{* *} \\
(0.01)\end{array}$ & $\begin{array}{l}0.03^{* *} \\
(0.01)\end{array}$ \\
\hline Observations & 476,748 & 476,748 & 144,858 & 144,858 \\
\hline Time FE & No & Yes & No & Yes \\
\hline Industry FE & No & No & No & No \\
\hline Controls & No & No & No & No \\
\hline Reduced Sample & No & No & Yes & Yes \\
\hline \multicolumn{5}{|c|}{$\begin{array}{l}\text { Notes: Standard errors in parentheses, clustered at firm level. The unit of ob- } \\
\text { servation } \Delta \text { Debt is the change in the value of current total debt of the firm. } \\
\text { Repurchases is the difference between the value of stock purchases and stock } \\
\text { issuances from the statement of cash flows. } \Delta \text { Money is the change in firm cash } \\
\text { holding. Profits is the value of firm profit at the net of taxes. Investments is } \\
\text { equal to capital expenditure. Dividends is equal to the value of the dividends } \\
\text { payed. All variables are normalized by the value of total assets in } t-4 \text {. Column } \\
\text { (3) and (4) report results for the sample of firms that are net repurchasers, i.e. } \\
\text { firms for which Repurchases }>0 .^{*}, *^{*}, * * * \text { indicate significance at } 1 \%, 5 \% \text { and } \\
10 \% \text { level. }\end{array}$} \\
\hline
\end{tabular}

financing of repurchase increases significantly.

\section{Appendix D. Monetary Policy Shocks and EPS Sur- prise}

Here, we check that the probability of being below the EPS forecast is not influenced anyhow by both the monetary policy shock and the exogenous change in the firm' cost of debt due to the monetary policy shock itself. In practice, we consider the following specifications: 
Table C.2: Financing Buybacks (2)

\begin{tabular}{lcccc}
\hline \hline & $(1)$ & $(2)$ & $(3)$ & $(4)$ \\
& Repurchases & Repurchases & Repurchases & Repurchases \\
\hline Debt & $0.34^{* * *}$ & $0.33^{* * *}$ & $0.35^{* * *}$ & $0.35^{* * *}$ \\
& $(0.07)$ & $(0.07)$ & $(0.08)$ & $(0.08)$ \\
$\Delta$ Money & & & & \\
& $-0.12^{* *}$ & $-0.12^{* *}$ & $-0.09^{* * *}$ & $-0.09^{* * *}$ \\
Profits & $(0.06)$ & $(0.06)$ & $(0.03)$ & $(0.03)$ \\
& $0.34^{* * *}$ & $0.35^{* * *}$ & $0.48^{* * *}$ & $0.48^{* * *}$ \\
& $(0.06)$ & $(0.06)$ & $(0.06)$ & $(0.06)$ \\
Investments & $-0.23^{* * *}$ & $-0.22^{* * *}$ & $-0.19^{* * *}$ & $-0.19^{* * *}$ \\
& $(0.05)$ & $(0.04)$ & $(0.06)$ & $(0.06)$ \\
Dividends & & & & \\
& $0.05^{*}$ & $0.05^{*}$ & 0.00 & 0.00 \\
& $(0.03)$ & $(0.02)$ & $(0.03)$ & $(0.03)$ \\
\hline Observations & 476,748 & 476,748 & 144,858 & 144,858 \\
Time FE & No & Yes & No & Yes \\
Industry FE & No & No & No & No \\
Controls & No & No & No & No \\
Reduced Sample & No & No & Yes & Yes \\
\hline No & & & & \\
\hline
\end{tabular}

Notes: Standard errors in parentheses, clustered at firm level. The unit of observation Repurchases is the difference between the value of stock purchases and stock issuances from the statement of cash flows. $\Delta D e b t$ is the change in the value of current total debt of the firm. $\Delta$ Cash is the change in firm money holding. Profits is the value of firm profit at the net of taxes. Investments is equal to capital expenditure. Dividends is equal to the value of the dividends payed. All variables are in levels, and expressed in US dollars. Column (3) and (4) report results for the sample of firms that are net repurchasers, i.e. firms for which Repurchases $>0 .{ }^{*}, * *$, $* * *$ indicate significance at $1 \%, 5 \%$ and $10 \%$ level.

$$
\begin{gathered}
\mathbb{I}\left(\text { Distance }_{i, t}<0\right)=\alpha+\beta \text { Shock }_{t}+X_{i, t-j}^{\prime} \gamma+\theta_{t}+\epsilon_{i, t} \\
\mathbb{I}\left(\text { Distance }_{i, t}<0\right)=\alpha+\beta \Delta \widehat{\text { Yield }}_{i,(t-j, t-j-1)}+X_{i, t}^{\prime} \gamma+\theta_{t}+\epsilon_{i, t}
\end{gathered}
$$

where $\mathbb{I}($ Distance $<0)$ is the indicator variable that takes value one if the firm is currently below the EPS forecast, Shock is the monetary policy innovation out of a SVAR (see Appendix A for details), $\Delta \widehat{\text { Yield }}$ is the exogenous change in the 10 -years corporate yield as predicted by monetary policy shocks, i.e. we use the variable Shock as instrument for the cost of debt. $X$ controls for firm-level characteristics such as net income, Q-value of investment, a dummy indicating whether the firm has redistributed dividends in the first previous four quarters, a dummy indicating the quintile of asset the firms belong to, $\theta$ controls for year fixed effects and quarter fixed effects separately. 
Table D.1: Monetary Policy Shocks and EPS Surprise

\begin{tabular}{|c|c|c|c|c|}
\hline & $\begin{array}{c}(1) \\
\mathbb{I}(\text { Distance }<0) \\
\end{array}$ & $\begin{array}{c}(2) \\
\mathbb{I}(\text { Distance }<0) \\
\end{array}$ & $\begin{array}{c}(3) \\
\mathbb{I}(\text { Distance }<0) \\
\end{array}$ & $\begin{array}{c}(4) \\
\mathbb{I}(\text { Distance }<0) \\
\end{array}$ \\
\hline Shock $_{t}$ & $\begin{array}{c}0.00 \\
(0.00)\end{array}$ & & & \\
\hline Shock $_{t-1}$ & & $\begin{array}{l}-0.00 \\
(0.00)\end{array}$ & & \\
\hline$\Delta$ Yiel $_{(t, t-1)}$ & & & $\begin{array}{c}0.42 \\
(0.36)\end{array}$ & \\
\hline$\widehat{\Delta \text { Yiel }_{(t-1, t-2)}} d_{(}$ & & & & $\begin{array}{c}0.55 \\
(0.35)\end{array}$ \\
\hline Observations & 44,856 & 42606 & 30,075 & 28,732 \\
\hline Time FE & Yes & Yes & Yes & Yes \\
\hline Industry FE & Yes & Yes & Yes & Yes \\
\hline Controls $(X)$ & Yes & Yes & Yes & Yes \\
\hline Estimator & Ols & Ols & $2 \mathrm{sls}$ & $2 \mathrm{sls}$ \\
\hline
\end{tabular}

Notes: Standard errors in parentheses, clustered at firm level. The unit of observation $\mathbb{I}($ Distance $<0)$ is an indicator variable that takes value one if the firm is currently below the EPS forecast. Shock is an exogenous monetary innovation as from a SVAR (see Appendix A for details). $\Delta \widehat{\text { Yield }}$ is the exogenous change in the 10-years corporate yield as predicted by monetary policy shocks, i.e. when we use Shock to instrument the firm-level cost of debt. Control $X$ includes net income normalized by total assets in $t-4$, Q-value of investment, a dummy indicating whether the firm has redistributed dividends in the first previous four quarters, a dummy indicating the quintile of asset the firms belong to. $*, * *, * * *$ indicate significance at $1 \%, 5 \%$ and $10 \%$ level.

Since we want to be sure that monetary policy does not affect anyhow the realization of the EPS surprise, we check both the contemporaneous and one-period-lag effect of the shock and the implied change in the cost of debt on the indicator for the EPS surprise. Hence we consider these models for $j=\{0,1\}$.

Table D.1 shows results. From column (1) and (2) we find that the monetary policy shock has no contemporaneous or lagged effect on the probability for the firm to be offtarget. From column (3) and (4), we find the same when considering the exogenous change in the cost of debt (as explained by a monetary policy shock). These results validate our identification strategy: the two instruments used in the first stage analysis of Section 4.2 are orthogonal to each-other. 


\section{Appendix E. Share Buybacks, Monetary Policy and the Cost of Debt: the First Stage}

As explained in Section 4.2, we instrument the cost of debt $\Delta$ Yield with the variable Shock, i.e. the monetary policy innovations extracted from a SVAR. As in any two-stage least squares regression, this implies that the endogenous variable will be regressed over all instruments, exogenous variables and controls. In other words the initial stage is:

$$
\begin{aligned}
\Delta \text { Yield }_{i, t} & =\zeta_{1}+\mu_{1} \mathbb{I}\left(\text { Distance }_{i, t}<0\right)+\mu_{2} \text { Shock }_{t}+\mu_{3} \mathbb{I}\left(\text { Distance }_{i, t}<0\right) * \text { Shock }_{t} \\
& +\mu_{4} \text { Distance }_{i, t}+\mu_{5} \mathbb{I}\left(\text { Distance }_{i, t}<0\right) * \text { Distance }_{i, t}+\mu_{6} \text { Distance }_{i, t}^{2} \\
& +\mu_{7} \mathbb{I}\left(\text { Distance }_{i, t}<0\right) * \text { Distance }_{i, t}^{2}+\mu_{8} \text { Distance }_{i, t}^{3} \\
& +\mu_{9} \mathbb{I}\left(\text { Distance }_{i, t}<0\right) * \text { Distance }_{i, t}^{3}+X_{i, t}^{\prime} \xi+\theta_{t}+\eta_{i, t}
\end{aligned}
$$

where $\Delta$ Yield $_{i, t}$ is the change in the 10-years corporate yield, $\mathbb{I}\left(\right.$ Distance $\left._{i, t}<0\right)$ takes values 1 when the firm $i$ is off-target with respect to the analysts' EPS forecast, Shock is the monetary policy innovation as from a SVAR (see Appendix A), Distance $_{i, t}$ is the effective distance from the EPS forecast, the square and the cube of this measure and its interaction with $\mathbb{I}\left(\right.$ Distance $\left._{i, t}<0\right)$ control for non-linear behavior both at the left and righthand side of the discontinuity cut-off. Table E.1 shows results. As discussed in Section 4.1, there is no difference in terms of cost of debt for firms around the EPS cut-off. The fact that the coefficient on the indicator variable $\mathbb{I}($ Distance $<0)$ is always insignificant along all specifications corroborates this idea. Also the interaction term between this indicator variable and the monetary policy shock confirm that the information shock based on the earning forecast does not have any impact on the cost of debt for both firms above and below the cut-off. It is only the monetary shock that has a significant effect on the change in the cost of debt. The estimate of such impact is robust whether we control for firms characteristics alone, as in model (4), or we include also real variables, as in model (5). Moreover, the effect of the monetary policy shock on the change in the cost of debt, estimated here for the sample in the $[-0.02,0.02]$ bracket, is comparable in magnitude to what found in the Section 3.4 .

\section{Appendix F. Challenging our Identification Strategy}

Here we want to challenge what done in Section 4 in order to understand to which extent

our identification strategy is rigorous. In particular, we want to check whether using the 
Table E.1: First Stage

\begin{tabular}{lccccc}
\hline \hline & $(1)$ & $(2)$ & $(3)$ & $(4)$ & $(5)$ \\
& $\Delta$ Yield & $\Delta$ Yield & $\Delta$ Yield & $\Delta$ Yield & $\Delta$ Yield \\
\hline $\mathbb{I}($ Distance $<0)$ & & & & & \\
& -0.01 & 0.00 & 0.00 & 0.00 & 0.00 \\
Shock & $(0.04)$ & $(0.03)$ & $(0.03)$ & $(0.03)$ & $(0.03)$ \\
& & $0.58^{* *}$ & $0.59^{* *}$ & $0.59^{* *}$ & $0.58^{* *}$ \\
$\mathbb{I}($ Distance $<0) *$ Shock & & & -0.12 & -0.11 & -0.12 \\
& & & $(0.10)$ & $(0.09)$ & $(0.11)$ \\
& & & & & \\
\hline Observations & 31,263 & 31,263 & 31,263 & 31,263 & 30,494 \\
Time FE & Yes & Yes & Yes & Yes & Yes \\
Industry FE & No & No & No & Yes & Yes \\
Controls (polynomial, $X)$ & No & No & No & Yes & Yes \\
Controls $(Z)$ & No & No & No & No & Yes \\
\hline \hline
\end{tabular}

Notes: Standard errors in parentheses, clustered at firm level. For model (1) to (5), the unit of interest $\Delta Y$ ield, the change in the firm-level 10-years corporate yield. $\mathbb{I}($ Distance $<0)$ is an indicator variable that takes value one if the firm is below the EPS forecast before EPS manipulation. Shock is the exogenous monetary policy innovation as from a SVAR (See Appendix A). In column (4), we control for a polynomial of the variable Distance, i.e. the difference between the EPS forecast and the pre-manipulated EPS of the firm, interacted with the indicator $\mathbb{I}($ Distance $<0)$. $X$ controls for net income, normalized by total asset in $t-1$, Q-value of investment, a dummy indicating whether the firm has redistributed dividends in the first previous four quarters, a dummy indicating the quintile of asset the firms belong to. In column (5), we control for $Z$ : capital investment and employment, both normalized by total asset in $t-4 .^{*}, * *, * * *$ indicate significance at $1 \%, 5 \%$ and $10 \%$ level.

monetary policy shocks (Shock) instead of the instrumented change in the cost of debt $(\widehat{\Delta Y i e l} d)$ in equation (7) leads to similar results to those from Table 8 of Section 4.2.

First Stage: EPS Distance from Forecast and Monetary Policy Shocks Here we study how monetary policy innovations affect repurchasing behavior of firms around the discontinuity. Similarly to what we do in Section 4, we consider only firms with Distance $_{i, t}$ in the $[-0.02 \$,+0.02 \$]$ bracket, and estimate the following 1st stage regression

$$
\begin{aligned}
\text { Repurchase }_{i, t} & =\alpha_{1}+\beta_{1} \mathbb{I}\left(\text { Distance }_{i, t}<0\right)+\beta_{2} \text { Shock }_{t}+\beta_{3} \mathbb{I}\left(\text { Distance }_{i, t}<0\right) * \text { Shock }_{t} \\
& +\beta_{4} \text { Distance }_{i, t}+\beta_{5} \mathbb{I}\left(\text { Distance }_{i, t}<0\right) * \text { Distance }_{i, t}+\beta_{6} \text { Distance }_{i, t}^{2} \\
& +\beta_{7} \mathbb{I}\left(\text { Distance }_{i, t}<0\right) * \text { Distance }_{i, t}^{2}+\beta_{8} \text { Distance }_{i, t}^{3} \\
& +\beta_{9} \mathbb{I}\left(\text { Distance }_{i, t}<0\right) * \text { Distance }_{i, t}^{3}+X_{i, t}^{\prime} \gamma+\theta_{t}+\epsilon_{i, t}
\end{aligned}
$$

where Repurchases ${ }_{i, t}$ is the level of net repurchase normalized by the level of assets in $t-4$, $\mathbb{I}\left(\right.$ Distance $\left._{i, t}<0\right)$ takes values 1 when the firm $i$ is off-target with respect to the analysts' 
EPS forecast, Shock is the monetary policy innovation as from a SVAR (see Appendix A), Distance $_{i, t}$ is the effective distance from the EPS forecast, the square and the cube of this measure and its interaction with $\mathbb{I}\left(\right.$ Distance $\left._{i, t}<0\right)$ control for non-linear behavior both at the left and right-hand side of the discontinuity cut-of, $X$ is usual set of firm-level characteristics.

Table F.1 shows results. Very closely to what obtained in Section 4.1, firms off-target repurchase $1 \%$ more (column (1)). When we control for the monetary policy shock, we find no significant impact on the size of the repurchase program (column (2)). When we control for the interaction term $\mathbb{I}\left(\right.$ Distance $\left._{i, t}<0\right) *$ Shock $_{t}$ and further controls, we find a negative and significant impact of monetary policy among firms off-target. In words, if a firm needs to buyback to adjust the EPS in the same quarter in which a negative shock realizes, then the firm will be able to repurchase more. How much more? For a $1 \%$ negative innovation on the Fed fund rate, firms off-target buy back $0.38 \%$ more. Is this result comparable with the one from Table 6 ? There we found that $1 \%$ decrease in the corporate cost of debt among firms off-target leads to an increase of repurchases by $0.44 \%$. The difference is $0.6 \%$ and it is explained by heterogeneity in the firm-level cost of debt.

Second Stage: Repurchase and Real Variables Here we complete our analysis by investigating the impact of share buybacks on capital investments and employment. The following regression quantifies this effect:

$$
\begin{aligned}
\bar{Y}_{i,(t+1, t+4)}-\bar{Y}_{i,(t-4, t-1)} & =\alpha_{0}+\xi_{1} \text { Repurchase }_{i, t}+\xi_{2} \text { Shock }+\xi_{3} \text { Repurchase }_{i, t} * \text { Shock }_{t} \\
& +\xi_{4} \text { Distance }_{i, t}+\xi_{5} \mathbb{I}\left(\text { Distance }_{i, t}<0\right) * \text { Distance }_{i, t}+\xi_{6} \text { Distance }_{i, t}^{2} \\
& +\beta_{7} \mathbb{I}\left(\text { Distance }_{i, t}<0\right) * \text { Distance }_{i, t}^{2}+\beta_{8} \text { Distance }_{i, t}^{3} \\
& +\beta_{9} \mathbb{I}\left(\text { Distance }_{i, t}<0\right) * \text { Distance }_{i, t}^{3}+X_{i, t}^{\prime} \omega+\theta_{t}+\epsilon_{i, t}
\end{aligned}
$$

where the dependent variable is the difference between the mean value of $Y$ in the next four quarters and in the previous four quarters, with $Y$ being either capital investments or employment. All variables are normalized by the level of assets in $t-4$.

Column (4) and (5) of Table F.1 reports two-stage least squares estimates with the variable Repurchases instrumented with the variable $\mathbb{I}($ Distance $<0) .{ }^{13}$ From this estimation we find that the crowding-out effect of $1 \%$ increase in repurchase on investment is $4 \%(5 \%$

\footnotetext{
${ }^{13}$ In column (4) and (5) We control for net income (normalized by total assets in $t-4$ ), Q-value of investment, a dummy indicating whether the firm has redistributed dividends in the first previous four quarters, a dummy indicating the quintile of asset the firms belong to, a polynomial of the variable Distance, interacted with the indicator $\mathbb{I}($ Distance $<0)$.
} 
Table F.1: EPS Surprise as unique IV

\begin{tabular}{|c|c|c|c|c|c|}
\hline & $\begin{array}{c}(1) \\
\text { Repurchases } \\
\end{array}$ & $\begin{array}{c}(2) \\
\text { Repurchases }\end{array}$ & $\begin{array}{c}(3) \\
\text { Repurchases }\end{array}$ & $\begin{array}{c}(4) \\
\Delta I n v .\end{array}$ & $\begin{array}{c}(5) \\
\Delta E m p .\end{array}$ \\
\hline $\mathbb{I}($ Distance $<0)$ & $\begin{array}{c}0.01^{* * *} \\
(0.00)\end{array}$ & $\begin{array}{c}0.01^{* * *} \\
(0.00)\end{array}$ & $\begin{array}{l}0.01^{* *} \\
(0.00)\end{array}$ & & \\
\hline Shock & & $\begin{array}{l}-0.002 \\
(0.002)\end{array}$ & $\begin{array}{l}-0.001 \\
(0.001)\end{array}$ & & \\
\hline $\mathbb{I}($ Distance $<0) *$ Shock & & & $\begin{array}{c}-0.004^{* * *} \\
(0.001)\end{array}$ & & \\
\hline Repurchases & & & & $\begin{array}{c}-0.041^{* * *} \\
(0.010)\end{array}$ & $\begin{array}{l}-1.438^{*} \\
(0.741)\end{array}$ \\
\hline Shock & & & & $\begin{array}{c}-0.0023^{* * *} \\
(0.000)\end{array}$ & $\begin{array}{c}-0.035^{* *} \\
(0.016)\end{array}$ \\
\hline Repurchases $*$ Shock & & & & $\begin{array}{c}0.018^{* * *} \\
(0.006)\end{array}$ & $\begin{array}{l}0.194^{*} \\
(0.115)\end{array}$ \\
\hline Observations & 44,856 & 44,856 & 43,389 & 34,437 & 31,237 \\
\hline Time FE & Yes & Yes & Yes & Yes & Yes \\
\hline Industry FE & No & No & Yes & Yes & Yes \\
\hline Controls (polinomial, $X$ ) & No & No & Yes & Yes & Yes \\
\hline 1st Stage & Yes & Yes & Yes & No & No \\
\hline 2nd Stage & No & No & No & Yes & Yes \\
\hline
\end{tabular}

Notes: Standard errors in parentheses, clustered at firm level. In columns (1) to (3), the unit of observation Repurchases is the difference between the value of stock purchases and stock issuances from the statement of cash flows. $\mathbb{I}($ Distance $<0)$ is an indicator variable that takes value one if the firm is currently below the EPS forecast. Shock is an exogenous monetary innovation as from a SVAR (see Appendix A for details). In columns (4), the unit of observation $\Delta$ Inv. is the difference between the mean value of capital investments in the next four quarters and in the previous four quarters, normalized by total asset in $t-4$. In columns (5), the unit of interest $\Delta E m p$. is the difference between the mean level of employment in the next four quarters and in the previous four quarters, normalized by total asset in $t-4$. Column (3) is the 1st stage regression where the endogenous variable Repurchases is instruments with $\mathbb{I}($ Distance $<0)$, Shock and their interaction. Column (4) and (5) report the 2nd stage regression when the dependent variable is respectively the change in investments and employment. We control for a polynomial of the variable Distance, i.e. the difference between the EPS forecast and the pre-manipulated EPS of the firm, interacted with the indicator $\mathbb{I}($ Distance $<0)$. $X$ controls also for net income normalized by total asset in $t-4$, Q-value of investment, a dummy indicating whether the firm has redistributed dividends in the first previous four quarters, a dummy indicating the quintile of asset the firms belong to. When considering the 2 nd stage. ${ }^{*}, * *,{ }^{* * *}$ indicate significance at $1 \%, 5 \%$ and $10 \%$ level.

from Table 8 of Section 4.2), while on employment is $144 \%$ (120\% from Table 8 of Section 4.2). The direct effect of the monetary policy shock and its interaction with the variable Repurchases are very close to the ones from 8 of Section 4.2: a $1 \%$ accommodative shock leads to $0.23 \%$ (3.50\%) increase in investments (employment); conducting a $1 \%$ repurchase in coincidence of a $1 \%$ accommodative shock leads to $1.80 \%$ (19.40\%) decrease in investments 
(employment) such that the crowding-out effect of repurchase on investments exacerbates. 